\title{
Investigation of Soil at Different Locations of the Kathmandu Valley of Nepal
}

\author{
Neeru K. C. , Khet Raj Dahal \\ Department of Construction Engineering and Management, Lumbini Buddhist University, Lumbini International Academy of Science and \\ Technology, Manbhawan, Lalitpur, Nepal
}

Email address:

neerukc1983@gmail.com (Neeru K. C.),krdahal@liast.edu.np (Dahal K. R)

${ }^{*}$ Corresponding author

\section{To cite this article:}

Neeru K. C., Khet Raj Dahal. Investigation of Soil at Different Locations of the Kathmandu Valley of Nepal. American Journal of Science, Engineering and Technology. Vol. 5, No. 4, 2020, pp. 154-169. doi: 10.11648/j.ajset.20200504.16

Received: December 7, 2020; Accepted: December 15, 2020; Published: December 31, 2020

\begin{abstract}
Investigation of soil bearing capacity helps in determining the design of the foundation of any structure. The main parameters which are commonly associated with the determination of liquefaction potential are the saturated sand and silty soils. Therefore, the present study was focused on the investigation of soil bearing capacity at different locations of Kathmandu valley of Nepal. The study was conducted during the period of 2019 . Laboratory tests of the soil is the major tool of the investigation. The findings were analyzed in five categories emphasizing on bearing capacity, bulk density, natural moisture content, specific gravity and grain sieve analysis. The study found that the soil bearing capacity of the Kathmandu valley is low. Most of the places consist of Silty Clay soil, the consistency of which is very low. The study found that the highest and lowest value of bearing capacity was to be $151.2 \mathrm{Kn} / \mathrm{m}^{2}$ and $61.66 \mathrm{Kn} / \mathrm{m}^{2}$ respectively in Lalitpur District. Similarly, the highest and lowest value of bearing capacity of Kathmandu was found to be $163 \mathrm{Kn} / \mathrm{m}^{2}$ and $58.6 \mathrm{Kn} / \mathrm{m}^{2}$, whereas the same parameter in Bhaktapur, was found to be $6 \mathrm{Kn} / \mathrm{m}^{2}$ and $56.4 \mathrm{Kn} / \mathrm{m}^{2}$. Furthermore, the highest and lowest value of bulk density of the Lalitpur district was found to be $1.72 \mathrm{gm} / \mathrm{cm}^{3}$ and $2.1 \mathrm{gm} / \mathrm{cm}^{3}$ respectively, and for Bhaktapur it was declared to be 1.69 $\mathrm{gm} / \mathrm{cm}^{3}$ and $2.01 \mathrm{gm} / \mathrm{cm}^{3}$ consecutively. In addition, the highest and lowest value of bulk density was calculated to be 1.55 $\mathrm{gm} / \mathrm{cm}^{3}$ and $2.09 \mathrm{gm} / \mathrm{cm}^{3}$ for Kathmandu. Whereas, based on natural moisture content, the findings which were observed are the highest and lowest value of $4.4 \%$ and $99.85 \%$ at Lalitpur; and at Bhaktapur $10.72 \%, 75.95 \%$ respectively. Similarly, the highest and lowest value of Kathmandu district was found to be $4.76 \%$ and $99.8 \%$. Moreover, based on specific gravity the highest and lowest values of Lalitpur District are 2.71 and 2.55, and at Bhaktapur district are 2.72 and 2.55, and at Kathmandu district are 2.72 and 2.55 respectively. Thus, the consistency of the soil at most of the places of the Kathmandu Valley ranges from soft to medium soft depending upon the value of $\mathrm{N}$ (i.e. 4 to 8). The study would like to suggest that the geotechnical investigation is necessary before the construction of a building in Kathmandu valley. Furthermore, the depth of the foundation should be increased, raft foundation is recommended to a greater extent. And, pile foundation is recommended, where the soil has very low bearing capacity.
\end{abstract}

Keywords: Bulk Density, Soil Bearing Capacity, Moisture Content, History of Construction Project

\section{Introduction}

Investigation of soil bearing capacity helps in determining the design of the foundation of any structure [1]. The main parameters which are commonly associated with the determination of liquefaction potential are the saturated sand and silty soils [2]. Gongabu is mainly covered by two different soil category, which is recent fluvial sediments and old lakebed sediments in accordance with the geological map of Kathmandu. A total of 28 buildings, including masonry and reinforced structure ( $\mathrm{RC})$, collapsed within the red zone. Nine buildings that were collapsed were found to be set on the epoch deposit, whereas the remaining nineteen damaged buildings were made on the Holocene deposit near the Bishnumati stream. Therefore, the more modern soft alluvium of stream origin had a big impact on the earth- 
quake damage structure within the Gongabu area [3].

The appropriate data is considered as the keystone of any successful design. The main purpose of that is to produce knowledge regarding the engineering properties of the soil for the right style and safe construction of a project. The site investigation is an essential part of geotechnical investigation, which plays a significant role to provide the data [4].

Model and parameter uncertainties are considered as necessary properties while selecting a reliable and safe model application. Uncertainty analyses are very essential in foundation engineering [5]. Differential settlement of the foundations takes place, while constructed on the soft ground if adoption of the foundation system is incorrect. Most of the civil engineering structures need special attention throughout the construction of such sites in order to overcome the adverse effects. It is really a big challenge to the Geotechnical Engineers in designing necessary infrastructures with economic foundations [6].

\section{Literature Review}

All construction projects are created on the soil. The soil has to bear the load of the structures. The soil testing before construction is the first and vital step for several reputed construction companies. Soil testing is primarily done to check the bearing capacity of the soil. It also helps in determining the physical and chemical composition of the soil. These characteristics could vary from layer to layer of the same soil. The characteristics of the soil may vary within the small area due to change in weather and climate and the management of the site may also change the bearing capacity of the soil [7].

Foundation is outlined because of the lowest part of a structure that provides a base for the super-structure and transmits the hundreds on the structure as well as the dead weight of the structure itself to the soil below. Foundation may be generally classified into two types: Deep Foundations and Shallow Foundation. The foremost common types of construction touching on deep foundation area unit following types of construction: Piles and Cofferdams [8]. The weathering of solid rock forms soil, a complex material. Soil is thought to be the foremost vital material that is employed for the development of engineering structures. The bearing capacity of the soil is one of vital parameters to support the load coming over its unit area. There are numerous methods for calculation of bearing capacity of soil given by many scientists like Prandtl, Terzaghi, Meyerhoff, Hansen, Vesic, and others. Types of soil, breadth of foundation, soil weight in the shear zone, and surcharge are the most factors influencing the bearing capacity. Structural rigidity and the contact stress distribution don't greatly influence bearing capacity. Bearing capacity analysis assumes a homogenous contact pressure between the foundation and underlying soil [9].

Shallow foundations are found to be engineered about to the bottom surface, wherever the soils are found to be unsaturated. Because of this reason, estimation of the bearing capacity of shallow foundations using conventional soil mechanics that could underestimate the bearing capacity values and may lead to conservative and costly foundation design [10].

The primary need of the foundation is considered as the bearing capacity in the field of Geotechnical engineering. The loads from superstructures are supposed to be transferred through foundation safely and economically to the soil underlying below. The ultimate bearing capacity of the foundation is defined as the load shear failure of the soil beneath the foundation occurs [11]. The forces and moments from the superstructure are transferred by the foundation to the soil below so that the stresses are distributed within the permissible limits, which provides stability against overturning and sliding to the superstructure. It's a transition between the structure and foundation soil. The work of a geotechnical engineer is to make sure that each foundation and soil below are safe against failure and not to experience excessive settlement [11]. The grain size distribution of soils is one of the main parameters in providing an initial understanding of the physical and mechanical behavior of soils [12]. When a failure happens, geotechnical engineers, engineering geologists, and geophysicists assign its cause to the events, which immediately precedes the failure, like an earthquake, massive rain, flood, or natural occurrence [13].

Unfulfilled geological formations and spring water conditions are liable for failures of the many geotechnical systems and increase construction prices. Very often builders/developers tend to ignore any geotechnical investigations and only conduct detailed investigations before construction of any major projects. From geotechnical engineers' point of view, to advance their information and style skills, it would be recommendable to supply appropriate instrumentation too, for observance of the post-construction behavior of structures. Each of these measures is typically thought of as extra expenditures on the budget of the project and hence neglected. These days only some projects consider and perform limited geotechnical investigations as the instrumentation is given less importance. In general, the geotechnical engineering practice in this area is extremely poor. New building rules are made by the local district administration, creating geotechnical investigations mandatory. Therefore, in the last five years, few builders get standard penetration test (SPT) is conducted at some locations to determine the idea of the soil strata at the site. In some cases, rarely, plate load tests and pile load tests are conducted. The piling is the last choice option. In most cases, the consultancies we get are deadly after the failure or collapse takes place. These are carried out not to analyze the causes of failure, but with a request to suggest appropriate remedial measure [14].

In recent studies, bulk density ( $\rho$ b) has been measured by using any one of the following two methods: (a) well established direct methods, or b) indirect methods. These two methods used different technology, the period of measurement, accuracy, cost, operator expertise, and quality 
to differing types of soil and conditions. - Direct Methods for measuring soil density are regarded as the more practical therefore more often utilized by agricultural soil scientists and civil engineers. They include measurements of the mass and volume of oven-dried soil samples. Direct measurements is obtained from core, excavation, and clod strategies. Variety of studies have found that these strategies depend upon measurements of the amount and mass of the soil sample as a result of the mass of a dry soil sample is obtained by weight, whereas the whole volume of the soil, as well as air and wetness, is determined by indirect measuring. The dry soil $\rho b$ will be calculated by using standard formula [15].

\section{Method of Study}

Tools used: Field observation and laboratory tests were used as the major tools of this study. Published papers, manuals, databases, standards, theses, and reports were also referred during the preparation of this paper.

Area of Study: The study was conducted in the Kathmandu valley of Nepal (Figure 1).

Period of study: The study was conducted during the period 2019.

The details of the geotechnical investigation of the proposed sites of the study area are presented in the table (Table 1). The study sites are presented in the table (Table 1).

Table 1. Geotechnical investigation sites

\begin{tabular}{lll}
\hline SN & Location of Geotechnical Investigation site & Number of Sites \\
\hline 1. & Kathmandu District & 29 \\
2. & Lalitpur District & 11 \\
3. & Bhaktapur District & 11 \\
& Total & 51 \\
\hline
\end{tabular}

The co-ordinates of the study sites are presented in the table (Table 2).

Study Area: The study area covers three districts of Kathmandu Valley which are Lalitpur, Bhaktapur and Kathmandu (Figure 1).

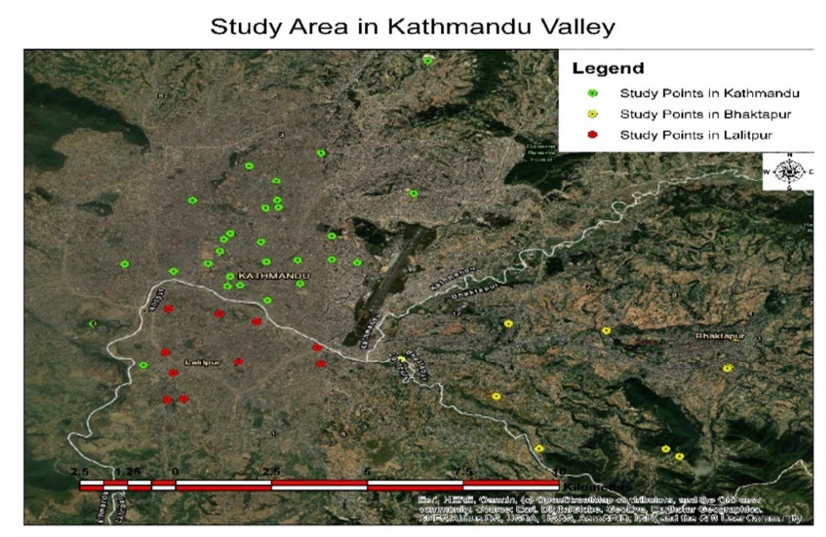

Figure 1. Study area of the research, Kathmandu Valley (Source: Google Map).

Data Collection: The process of collection of data includes both the primary and secondary data as well as qualitative and quantitative data. The following methods/ techniques were implied for the collection of data for the study.

Table 2. Represents the coordinates and the altitude of the Lalitpur sites

\begin{tabular}{|c|c|c|c|c|}
\hline \multicolumn{5}{|c|}{ Co-ordinates of the sites, Kathmandu, Lalitpur and Bhaktapur } \\
\hline \multicolumn{5}{|c|}{ a. Co-ordinates of the site taken in Lalitpur district } \\
\hline S.N. & $\begin{array}{l}\text { Geotechnical Investigation } \\
\text { Sites (Lalitpur) }\end{array}$ & Longitude & Latitude & Altitude $(\mathrm{m})$ \\
\hline 1 & Pulchowk & 85.317758 & 27.68293 & 1324 \\
\hline 2 & Balkumari & 85.3408 & 27.6724 & 1297 \\
\hline 3 & Phulbarichowk, Bhaisepati & 85.3095 & 27.6561 & 1296 \\
\hline 4 & Bhaisepati & 80.3056 & 28.6558 & 1341 \\
\hline 5 & Lagankhel & 85.3223 & 27.6679 & 1329 \\
\hline 6 & Chakupat & 85.3266 & 27.6805 & 1297 \\
\hline 7 & Balkumari & 85.3408 & 27.6724 & 1297 \\
\hline 8 & Nakhu & 85.307 & 27.6642 & 1293 \\
\hline 9 & Imadol & 85.3416 & 27.6672 & 1306.98 \\
\hline 10 & Sanepa & 85.305866 & 27.68445 & 1400 \\
\hline 11 & Bagdole & 85.3052 & 27.6709 & 1314 \\
\hline \multicolumn{5}{|c|}{ b. Co-ordinates of the site taken in Lalitpur district } \\
\hline 1 & Sundarnagar-3, Thimi & 85.3856 & 27.6799 & 1334 \\
\hline 2 & Sirutar & 85.3828 & 27.6569 & 1314 \\
\hline 3 & Madhyapur, Thimi & 85.38 & 27.68 & 1330 \\
\hline 4 & Balkot & 85.36 & 27.6684 & 1301 \\
\hline 5 & Duwakot & 85.4086 & 27.6777 & 1310 \\
\hline 6 & Bageshori-2 & 85.4389 & 27.6755 & 1340 \\
\hline 7 & Jagati & 85.4372 & 27.666 & 1328 \\
\hline 8 & Ram-Mandir-4 & 85.3928 & 27.6406 & 1376 \\
\hline 9 & Balkot & 83.3603 & 27.6687 & 1299 \\
\hline 10 & Suryabinayak, Jagati & 85.4369 & 27.6656 & 1326 \\
\hline 11 & Suryabinayak-7, Gundu & 85.4257 & 27.6382 & 1695 \\
\hline \multicolumn{5}{|c|}{ c. Co-ordinates of the site taken in the Lalitpur district } \\
\hline 1 & Teku & 85.3071 & 27.69615 & 1299 \\
\hline 2 & Maitighar & 85.3204 & 27.6945 & 1296 \\
\hline 3 & Bhadrakali & 85.3152 & 27.6985 & 1301 \\
\hline 4 & New Baneshwor & 85.3368 & 27.69234 & 1317 \\
\hline 5 & Exhibition Road & 85.318 & 27.7024 & 1302 \\
\hline 6 & Soltimode & 85.2925 & 27.6992 & 1298 \\
\hline 7 & Chandol & 85.3417 & 27.7332 & 1342 \\
\hline 8 & Thapagaun & 85.3227 & 27.69177 & 1313 \\
\hline 9 & Teku & 85.3071 & 27.69615 & 1299 \\
\hline 10 & Samakhusi & 85.3177 & 27.7349 & 1307 \\
\hline 11 & Badhepakha & 85.3667 & 27.7618 & 1355 \\
\hline 12 & Boudha, Tinchuli & 85.3683 & 27.7272 & 1359 \\
\hline 13 & Baluwatar & 85.3312 & 27.7244 & 1322 \\
\hline 14 & Bagbazar & 85.3189 & 27.7061 & 1306 \\
\hline 15 & Sinamangal & 85.3502 & 27.6988 & 1308 \\
\hline 16 & Anamnagar & 85.3289 & 27.6991 & 1301 \\
\hline 17 & Kamaladi & 85.3204 & 27.7079 & 1304 \\
\hline 18 & Baneshwor-10 & 85.3362 & 27.6996 & 1317 \\
\hline 19 & Bafal & 85.2858 & 27.701 & 1299 \\
\hline 20 & Panipokhari & 85.3248 & 27.7292 & 1338 \\
\hline 21 & Bhatbhateni & 85.3314 & 27.7183 & 1322 \\
\hline 22 & Dillibazar & 85.3276 & 27.7053 & 1306 \\
\hline 23 & Thapathali & 85.3197 & 27.6915 & 1301 \\
\hline 24 & Budhhanagar & 85.3291 & 27.6871 & 1295 \\
\hline 25 & Thamel & 85.3116 & 27.7182 & 1319 \\
\hline 26 & Tangal & 85.3317 & 27.7161 & 1321 \\
\hline 27 & Balkhu & 85.2884 & 27.6798 & 1317 \\
\hline 28 & Bhimsengola & 85.3442 & 27.6998 & 1323 \\
\hline 29 & Gaushala & 85.3442 & 27.7071 & 1326 \\
\hline
\end{tabular}

Machine used: Drilling works were carried out using one set of percussion drilling machines. The sides of the boreholes were lined with $150 \mathrm{~mm}$ casing pipes. Standard Penetration tests (SPT) were carried out in the boreholes at average depth intervals of $1.5 \mathrm{~m}$. Spilled spoon sampler of 35 
$\mathrm{mm}$ internal diameter and $50 \mathrm{~mm}$ external diameter coupled with a standard cutting shoe at its lower end was driven into the ground at the base of the borehole using a $63.5 \mathrm{~kg}$ hammer falling from a height of $760 \mathrm{~mm}$. After an initial 150 mm seating penetration the sampler was driven to a further depth of $150 \mathrm{~mm}$ twice to reach the final depth. The sum of the number of blows required to reach the two last final 150 mm depth was recorded as the $\mathrm{N}$-value.

Sample Size: The sample size was derived for the above condition by using Slovin's formula,

$n=\frac{N}{(1+N e 2)}$, Where, $\mathrm{n}=36.09$ no's, take $\mathrm{n}=37$

Where, $\mathrm{n}=$ Sample size, $\mathrm{N}=$ Population, $\mathrm{e}=$ margin of error

No of sample, $n=51 /(1+51 * 0.09 * 0.09)=36.09$. Thus, the sample size was fixed as 37 number

Among them, 17 (nos.) from Kathmandu, 10 (nos.) from Lalitpur and 10 (nos.) from Bhaktapur).

\section{Results}

\subsection{Soil profile of Geotechnical Investigation Sites}

The sample size of 37 geotechnical investigation sites was selected and interviewed in this process. The following are the findings and discussions concerning different categories.

Different parameters profile contributing soil bearing capacity.

\subsection{Grain Sieve Analysis}

\subsubsection{Lalitpur District}

The grain sieve analysis of Pulchowk is presented in the figure (Figure 2). The blue and red bars represent the percentage of gravel, sand, silt, and clay at depth $1.5 \mathrm{~m}$ and $16.5 \mathrm{~m}$ respectively.

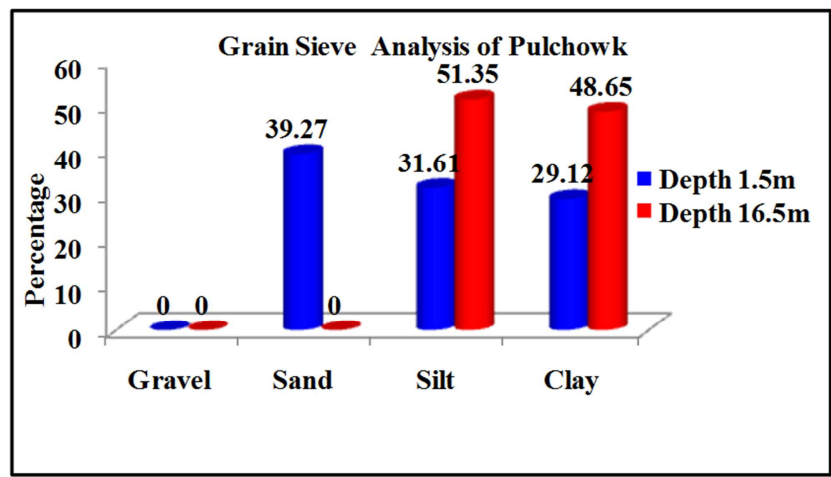

Figure 2. Grain Sieve Analysis of Pulchowk (Laboratory Test, 2019).

The grain sieve analysis of Phulbarichowk is presented in figure (Figure 3). The blue and red bars represent the percentage of gravel, sand, silt, and clay at depth $1.5 \mathrm{~m}$ and $12.0 \mathrm{~m}$ respectively.

The grain sieve analysis of Bhaisepati is presented in figure (Figure 4). The blue and red bars represent the percentage of gravel, sand, silt, and clay at depth $1.5 \mathrm{~m}$ and $7.5 \mathrm{~m}$ respectively.

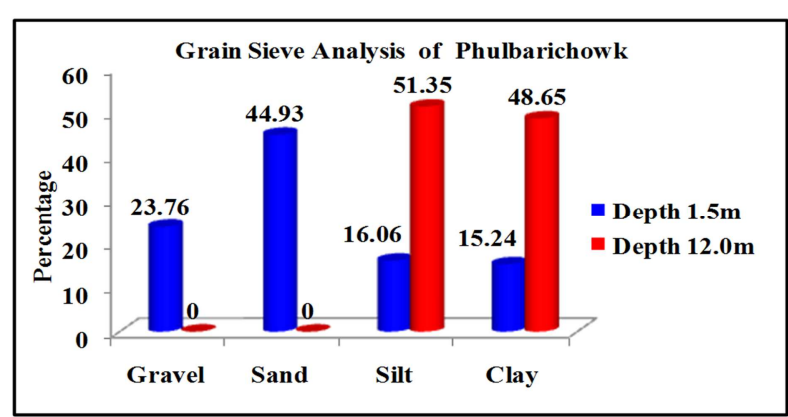

Figure 3. Grain Sieve Analysis of Phulbarichowk (Laboratory Test, 2019).

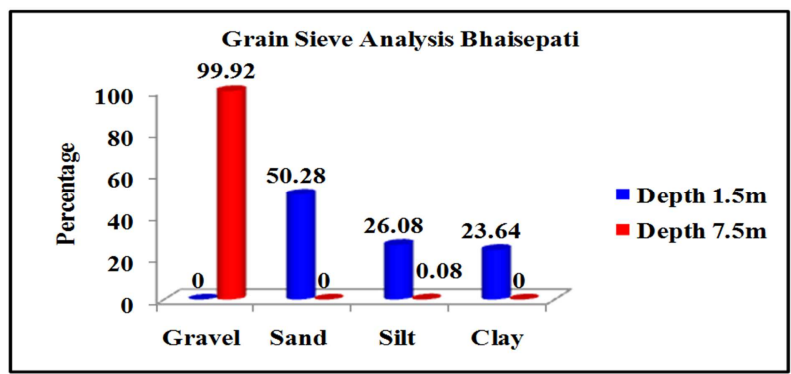

Figure 4. Grain Sieve Analysis of Bhaisepati (Laboratory Test, 2019).

The grain sieve analysis of Lagankhel is presented in the figure (Figure 5). The blue and red bars represent the percentage of gravel, sand, silt, and clay at depth $1.5 \mathrm{~m}$ and $10.5 \mathrm{~m}$ and $19.5 \mathrm{~m}$ respectively.

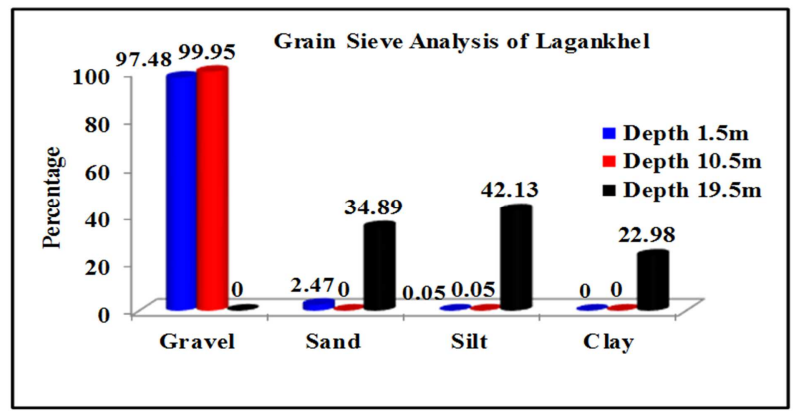

Figure 5. Grain Sieve Analysis of Lagankhel (Laboratory Test, 2019).

The grain sieve analysis of Chakupat is presented in figure (Figure 6). The blue and red bars represent the percentage of gravel, sand, silt, and clay at depth $1.5 \mathrm{~m}$ and $15.0 \mathrm{~m}$ respectively.

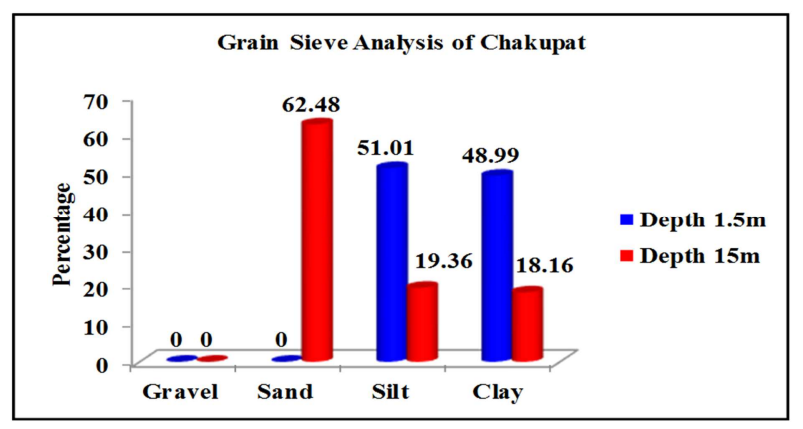

Figure 6. Grain Sieve Analysis of Chakupat (Laboratory Test, 2019). 
The grain sieve analysis of Balkumari is presented in figure (Figure 7). The blue and red bars represent the percentage of gravel, sand, silt, and clay at depth $1.5 \mathrm{~m}$ and $19.5 \mathrm{~m}$ respectively.

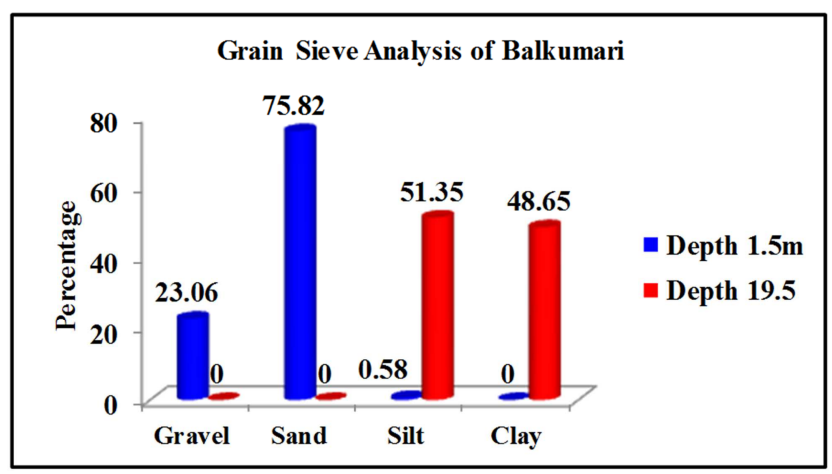

Figure 7. Grain Sieve Analysis of Balkumari (Laboratory Test, 2019).

The grain sieve analysis of Nakhu is presented in figure (Figure 8). The blue and red bars represent the percentage of gravel, sand, silt and clay at depth $1.5 \mathrm{~m}$ and $15.0 \mathrm{~m}$ respectively.

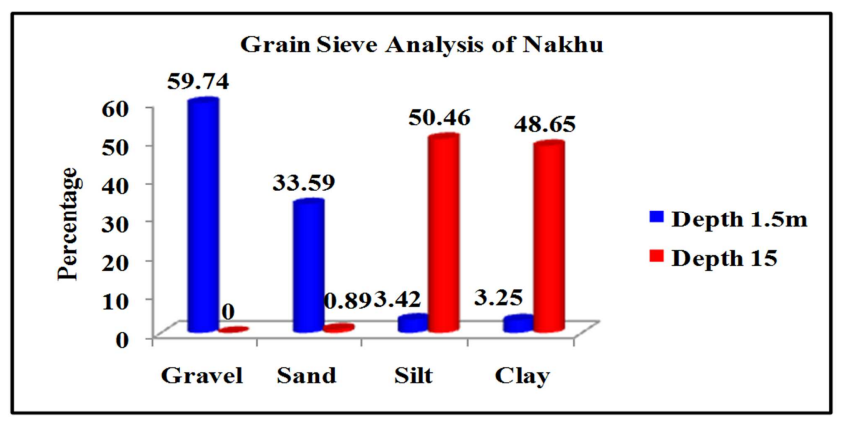

Figure 8. Grain Sieve Analysis of Nakhu (Laboratory Test, 2019).

The grain sieve analysis of Imadol is presented in the figure (Figure 9). The blue and red bars represent the percentage of gravel, sand, silt, and clay at depth $1.5 \mathrm{~m}$ and $12 \mathrm{~m}$ respectively.

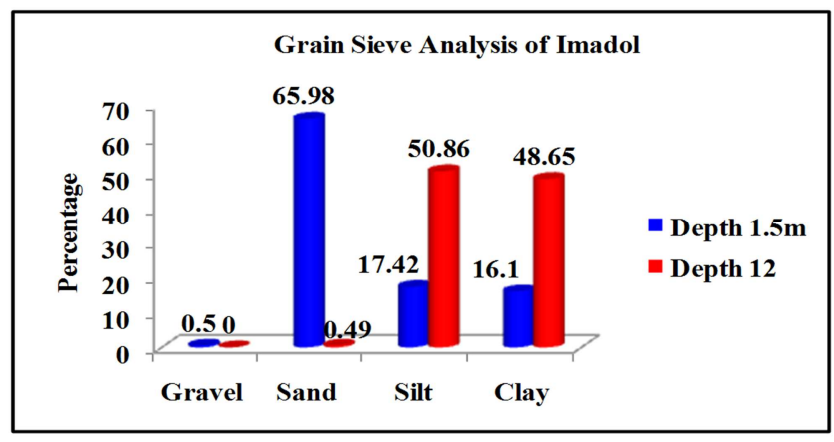

Figure 9. Grain Sieve Analysis of Imadol (Laboratory Test, 2019).

The grain sieve analysis of Sanepa is presented in the figure (Figure 10). The blue and red bars represent the percentage of gravel, sand, silt, and clay at depth $1.5 \mathrm{~m}$ and $13.5 \mathrm{~m}$ respectively.

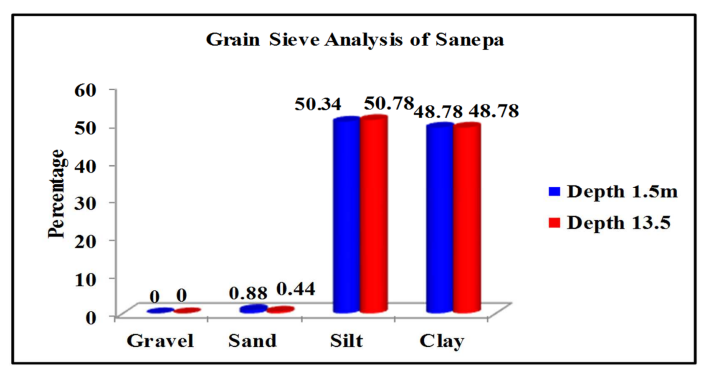

Figure 10. Grain Sieve Analysis of Sanepa (Laboratory Test, 2019).

The grain sieve analysis of Bagdole is presented in the figure (Figure 11). The blue and red bars represent the percentage of gravel, sand, silt, and clay at depth $1.5 \mathrm{~m}$ and $10.5 \mathrm{~m}$ respectively.

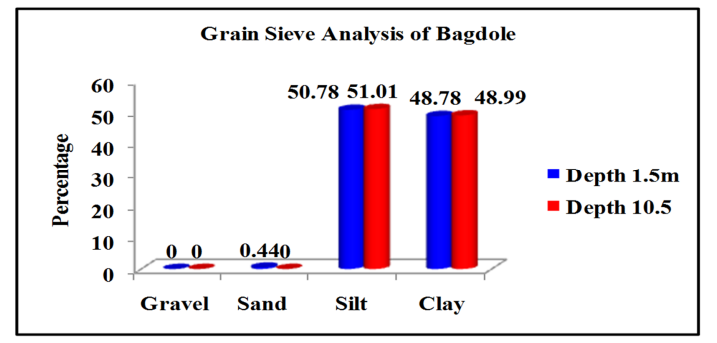

Figure 11. Grain Sieve Analysis of Bagdole (Laboratory Test, 2019).

\subsubsection{Bhaktapur District}

The grain sieve analysis of Sundarnagar-4, Thimi is presented in figure (Figure 12). The blue and red bars represent the percentage of gravel, sand, silt, and clay at depth $1.5 \mathrm{~m}$ and $9.0 \mathrm{~m}$ respectively.

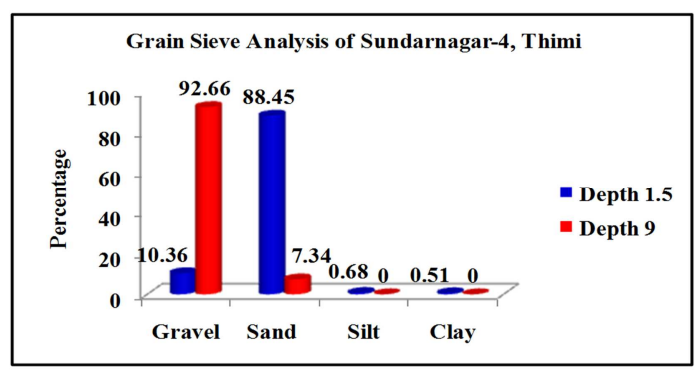

Figure 12. Grain Sieve Analysis of Sundarnagar-4, Thimi (Laboratory Test, 2019).

The grain sieve analysis of Sirutar is presented in the figure (Figure 13). The blue and red bars represent the percentage of gravel, sand, silt, and clay at depth $1.5 \mathrm{~m}$ and $12.0 \mathrm{~m}$ respectively.

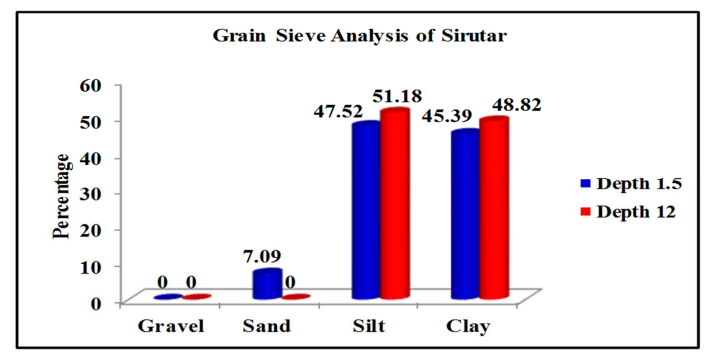

Figure 13. Grain Sieve Analysis of Sirutar (Laboratory Test, 2019). 
The grain sieve analysis of Madhyapur, Thimi is presented in figure (Figure 14). The blue and red bars represent the percentage of gravel, sand, silt, and clay at depth $1.5 \mathrm{~m}$ and $25.5 \mathrm{~m}$ respectively.

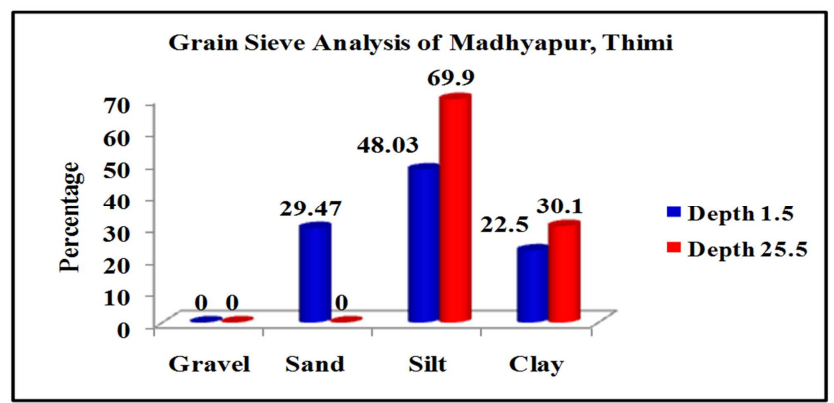

Figure 14. Grain Sieve Analysis of Madhyapur, Thimi (Laboratory Test, 2019).

The grain sieve analysis of Balkot is presented in the figure (Figure 15). The blue and red bars represent the percentage of gravel, sand, silt, and clay at depth $1.5 \mathrm{~m}$ and $9.0 \mathrm{~m}$ respectively.

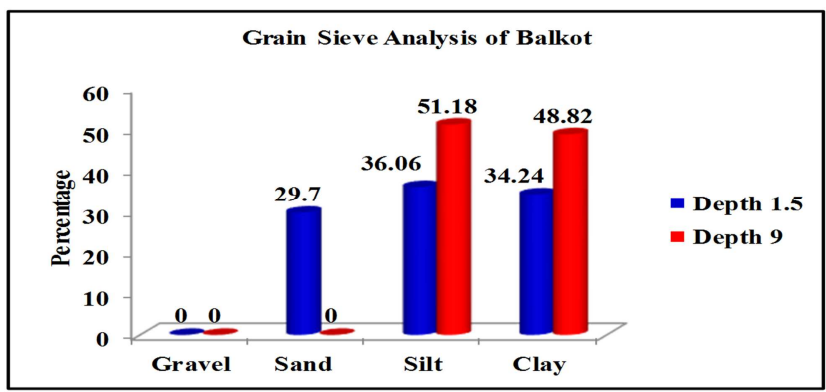

Figure 15. Grain Sieve Analysis of Balkot (Laboratory Test, 2019).

The grain sieve analysis of Duwakot is presented in the figure (Figure 16). The blue and red bars represent the percentage of gravel, sand, silt, and clay at depth $1.5 \mathrm{~m}$ and $9 \mathrm{~m}$ respectively.

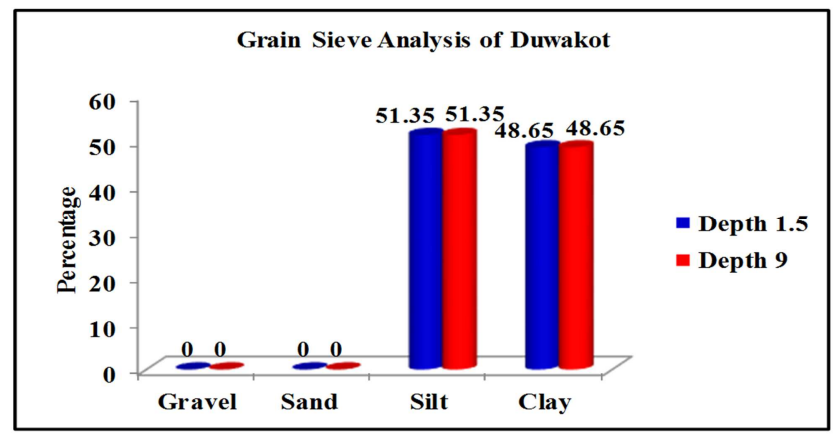

Figure 16. Grain Sieve Analysis of Duwakot (Laboratory Test, 2019).

The grain sieve analysis of Jagati is presented in the figure (Figure 17). The blue and red bars represent the percentage of gravel, sand, silt and clay at depth $1.5 \mathrm{~m}$ and $19.5 \mathrm{~m}$ respectively.

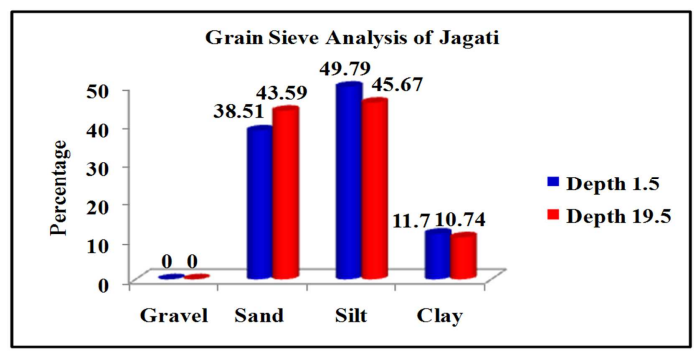

Figure 17. Grain Sieve Analysis of Jagati (Laboratory Test, 2019).

The grain sieve analysis of Rammandir-4 is presented in the figure (Figure 18). The blue and red bars represent the percentage of gravel, sand, silt and clay at depth $1.5 \mathrm{~m}$ and $10.5 \mathrm{~m}$ respectively.

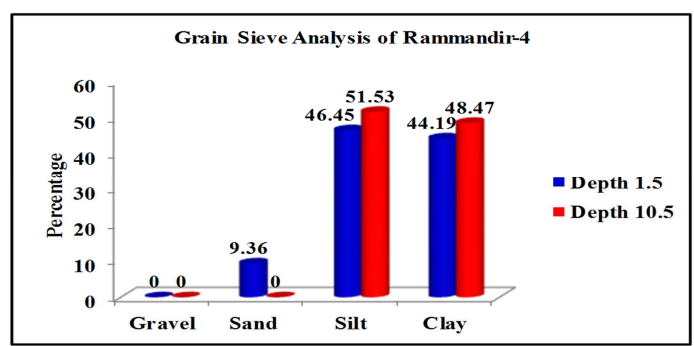

Figure 18. Grain Sieve Analysis of Rammandir-4 (Laboratory Test, 2019).

The grain sieve analysis of Balkot is presented in the figure (Figure 19). The blue and red bars represent the percentage of gravel, sand, silt and clay at depth $1.5 \mathrm{~m}$ and $13.5 \mathrm{~m}$ respectively.

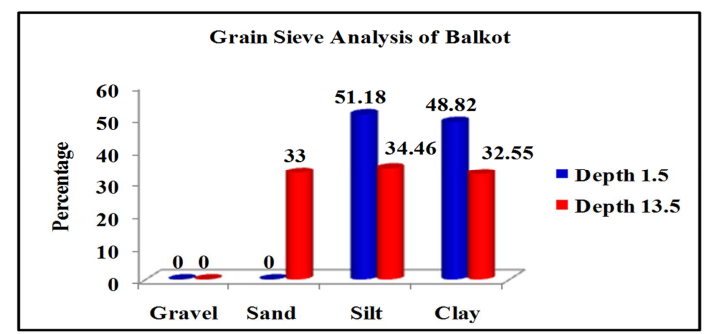

Figure 19. Grain Sieve Analysis of Balkot (Laboratory Test, 2019).

The grain sieve analysis of Bageshwori is presented in the figure (Figure 20). The blue and red bars represent the percentage of gravel, sand, silt and clay at depth $1.5 \mathrm{~m}$ and $13.5 \mathrm{~m}$ respectively.

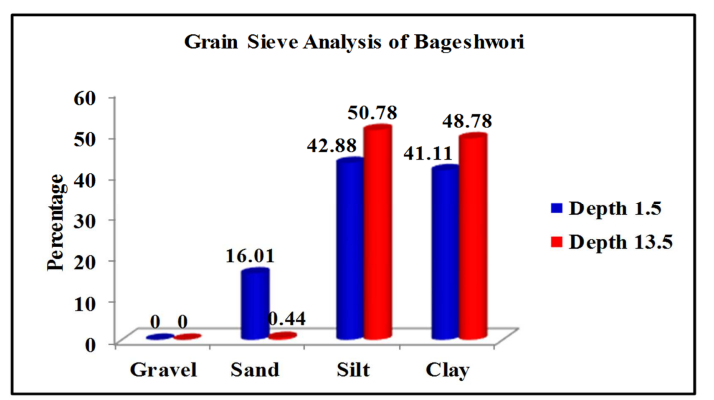

Figure 20. Grain Sieve Analysis of Bageshwori (Laboratory Test, 2019). 
The grain sieve analysis of Gundu is presented in the figure (Figure 21). The blue and red bars represent the percentage of gravel, sand, silt and clay at depth $1.5 \mathrm{~m}$ and $13.5 \mathrm{~m}$ respectively.

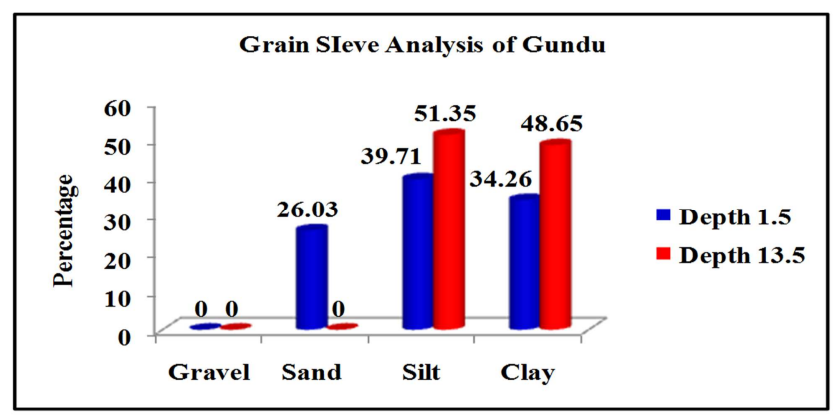

Figure 21. Grain Sieve Analysis of Gundu (Laboratory Test, 2019).

\subsubsection{Kathmandu District}

The grain sieve analysis of Teku is presented in the figure (Figure 22). The blue and red bars represent the percentage of gravel, sand, silt and clay at depth $1.5 \mathrm{~m}$ and $18.0 \mathrm{~m}$ respectively.

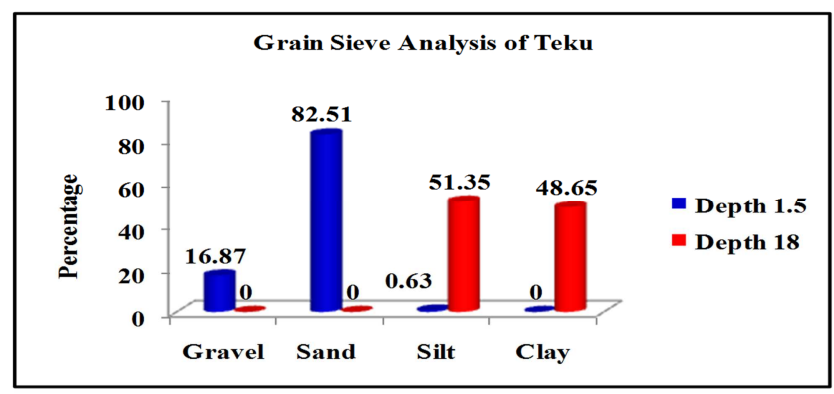

Figure 22. Grain Sieve Analysis of Teku (Laboratory Test, 2019).

The grain sieve analysis of Maitighar is presented in the figure (Figure 23). The blue and red bars represent the percentage of gravel, sand, silt and clay at depth $1.5 \mathrm{~m}$ and $10.5 \mathrm{~m}$ and $22.5 \mathrm{~m}$ respectively.

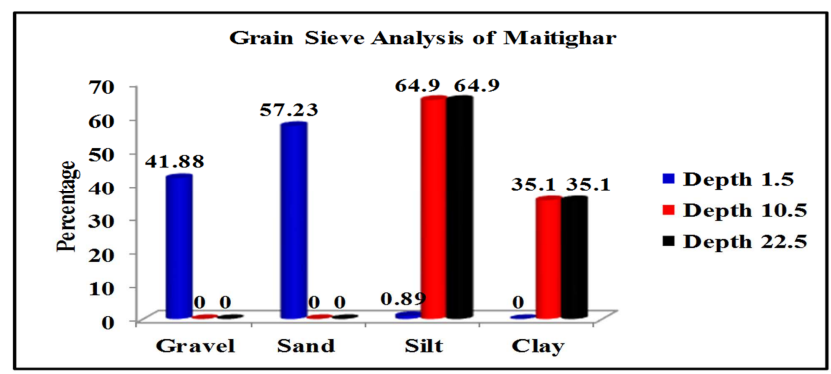

Figure 23. Grain Sieve Analysis of Maitighar (Laboratory Test, 2019).

The grain sieve analysis of New Baneshwor is presented in the figure (Figure 24). The blue and red bars represent the percentage of gravel, sand, silt and clay at depth $1.5 \mathrm{~m}$ and $15 \mathrm{~m}$ respectively.

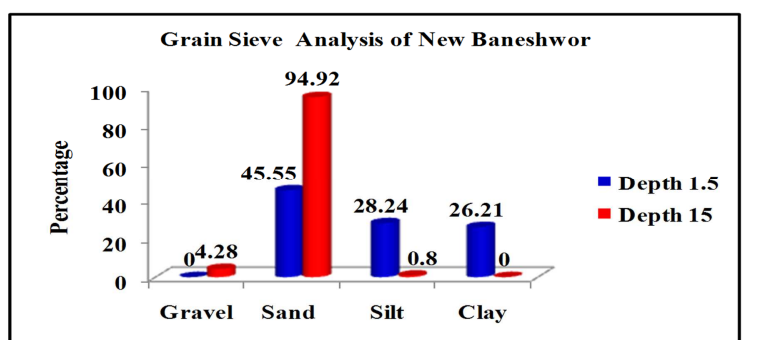

Figure 24. Grain Sieve Analysis of New Baneshwor (Laboratory Test, 2019).

The grain sieve analysis of Soltimode is presented in the figure (Figure 25). The blue and red bars represent the percentage of gravel, sand, silt and clay at depth $1.5 \mathrm{~m}$ and $13.5 \mathrm{~m}$ respectively.

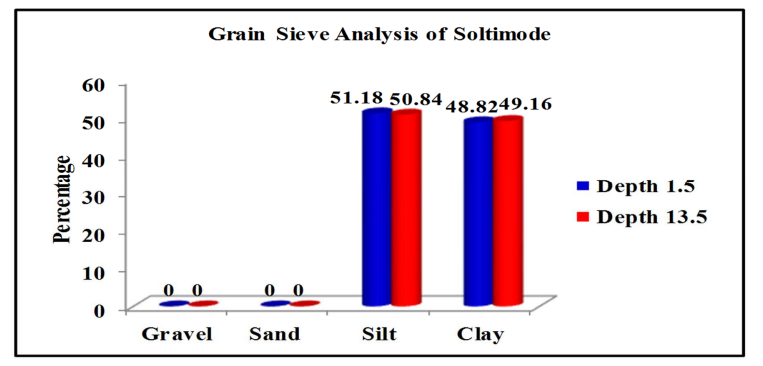

Figure 25. Grain Sieve Analysis of Soltimode (Laboratory Test, 2019).

The grain sieve analysis of Thapagaun is presented in the figure (Figure 26). The blue and red bars represent the percentage of gravel, sand, silt and clay at depth $1.5 \mathrm{~m}$ and $19.5 \mathrm{~m}$ respectively.

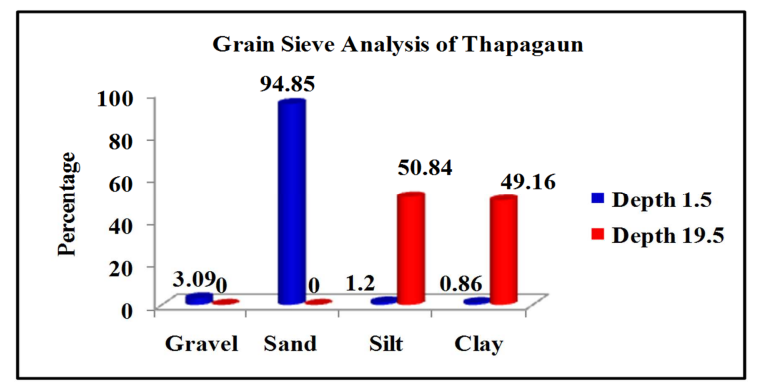

Figure 26. Grain Sieve Analysis of Thapagaun (Laboratory Test, 2019).

The grain sieve analysis of Bafal is presented in the figure (Figure 27). The blue and red bars represent the percentage of gravel, sand, silt and clay at depth $1.5 \mathrm{~m}$ and $15 \mathrm{~m}$ respectively.

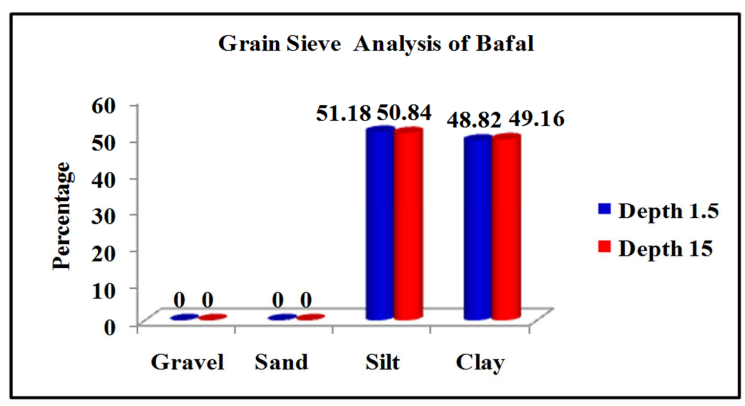

Figure 27. Grain Sieve Analysis of Bafal (Laboratory Test, 2019). 
The grain sieve analysis of Boudha is presented in the figure (Figure 28). The blue and red bars represent the percentage of gravel, sand, silt and clay at depth $1.5 \mathrm{~m}$ and $12 \mathrm{~m}$ respectively.

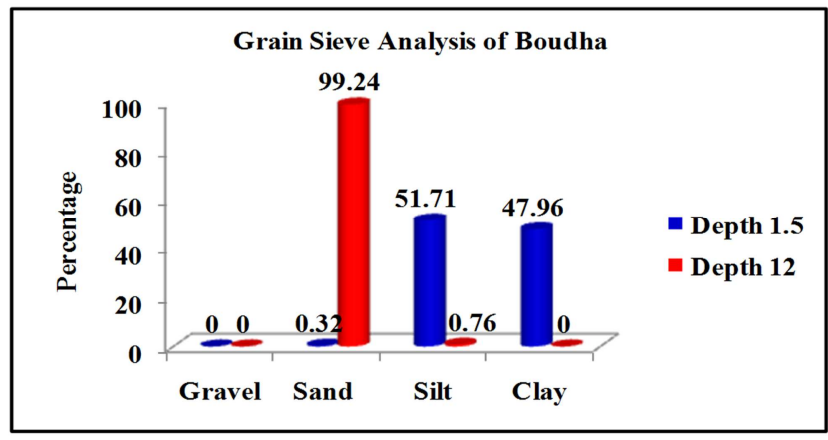

Figure 28. Grain Sieve Analysis of Boudha (Laboratory Test, 2019).

The grain sieve analysis of Baluwatar is presented in the figure (Figure 29). The blue and red bars represent the percentage of gravel, sand, silt and clay at depth $1.5 \mathrm{~m}$ and $15 \mathrm{~m}$ respectively.

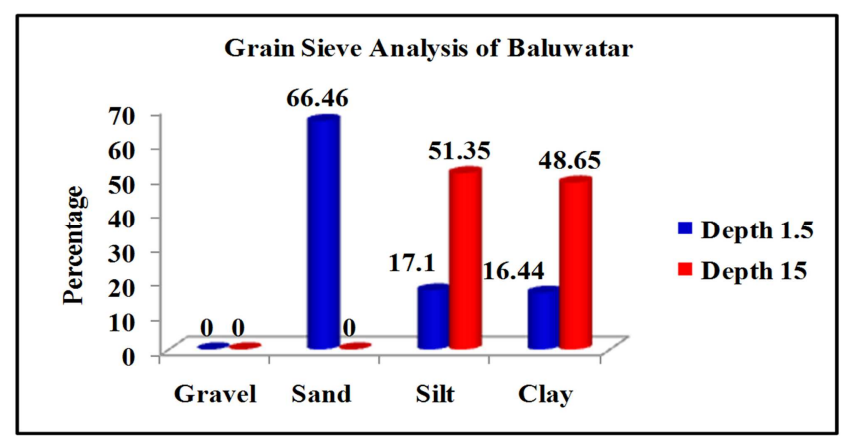

Figure 29. Grain Sieve Analysis of Baluwatar (Laboratory Test, 2019).

The grain sieve analysis of Sinamangal is presented in the figure (Figure 30). The blue and red bars represent the percentage of gravel, sand, silt and clay at depth $1.5 \mathrm{~m}$ and $9 \mathrm{~m}$ respectively.

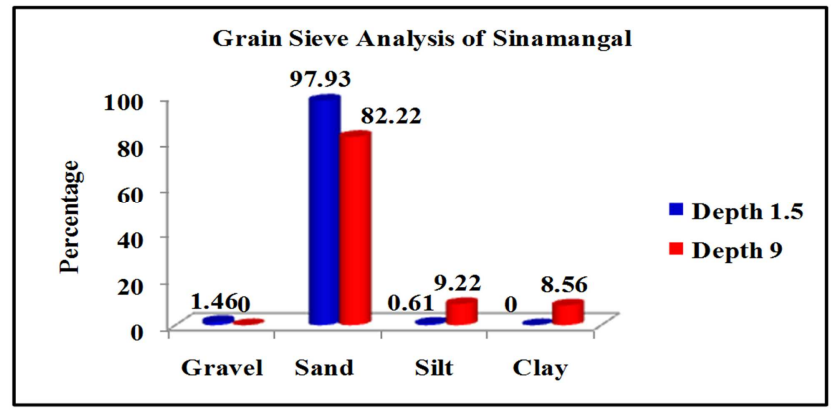

Figure 30. Grain Sieve Analysis of Sinamangal (Laboratory Test, 2019).

The grain sieve analysis of Bagbazar is presented in the figure (Figure 31). The blue and red bars represent the percentage of gravel, sand, silt and clay at depth $1.5 \mathrm{~m}$ and $16.5 \mathrm{~m}$ respectively.

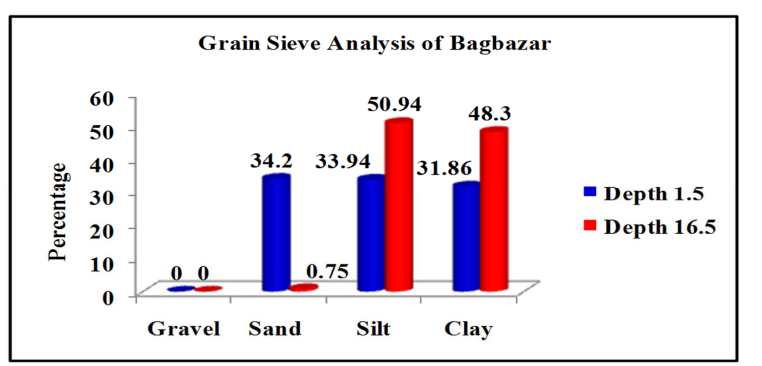

Figure 31. Grain Sieve Analysis of Bagbazar (Laboratory Test, 2019).

The grain sieve analysis of Kamaladi is presented in the figure (Figure 32). The blue and red bars represent the percentage of gravel, sand, silt and clay at depth $1.5 \mathrm{~m}$ and $18 \mathrm{~m}$ respectively.

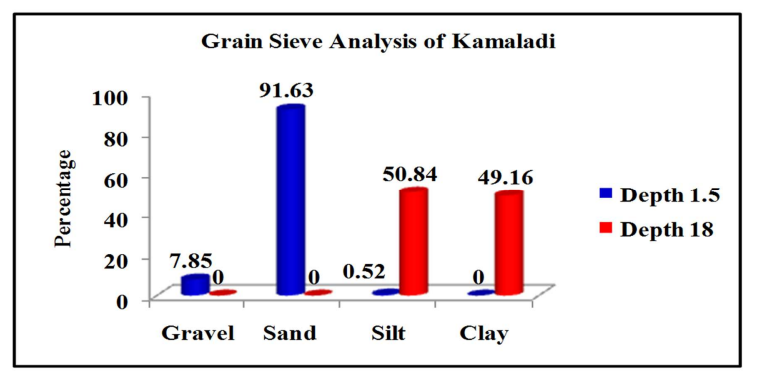

Figure 32. Grain Sieve Analysis of Kamaladi (Laboratory Test, 2019).

The grain sieve analysis of Panipokhari is presented in the figure (Figure 33). The blue and red bars represent the percentage of gravel, sand, silt and clay at depth $1.5 \mathrm{~m}$ and $12 \mathrm{~m}$ respectively.

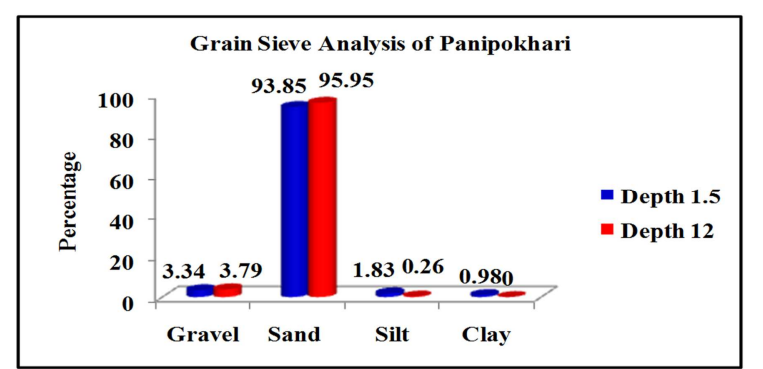

Figure 33. Grain Sieve Analysis of Panipokhari (Laboratory Test, 2019).

The grain sieve analysis of Bhatbhateni is presented in the figure (Figure 34). The blue and red bars represent the percentage of gravel, sand, silt and clay at depth $1.5 \mathrm{~m}$ and $13.5 \mathrm{~m}$ respectively.

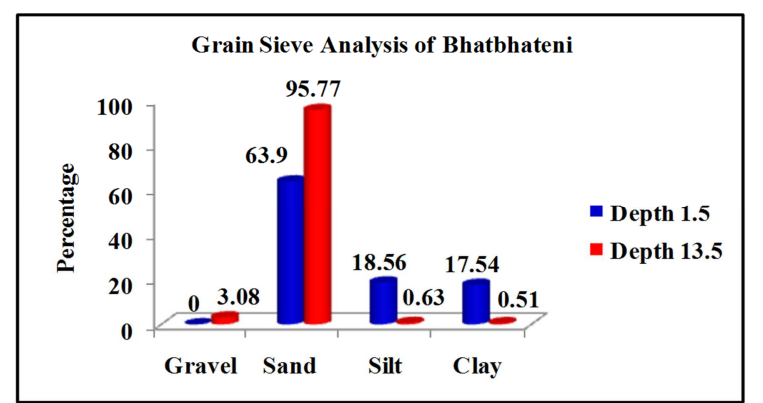

Figure 34. Grain Sieve Analysis of Bhatbhateni (Laboratory Test, 2019). 
The grain sieve analysis of Tangal is presented in the figure (Figure 35). The blue and red bars represent the percentage of gravel, sand, silt and clay at depth $1.5 \mathrm{~m}$ and $15 \mathrm{~m}$ respectively.

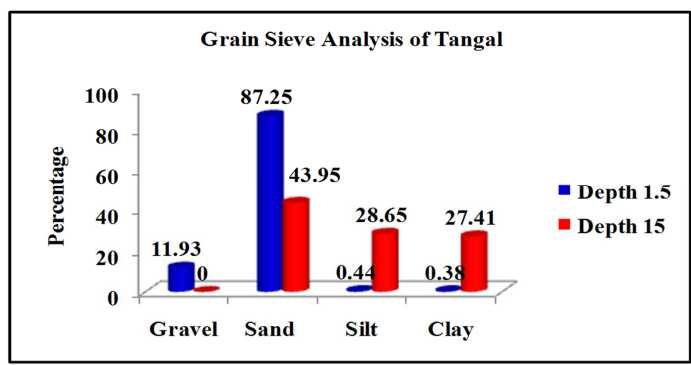

Figure 35. Grain Sieve Analysis of Tangal (Laboratory Test, 2019).

The grain sieve analysis of Buddhanagar is presented in the figure (Figure 36). The blue and red bars represent the percentage of gravel, sand, silt and clay at depth $1.5 \mathrm{~m}$ and $15 \mathrm{~m}$ respectively.

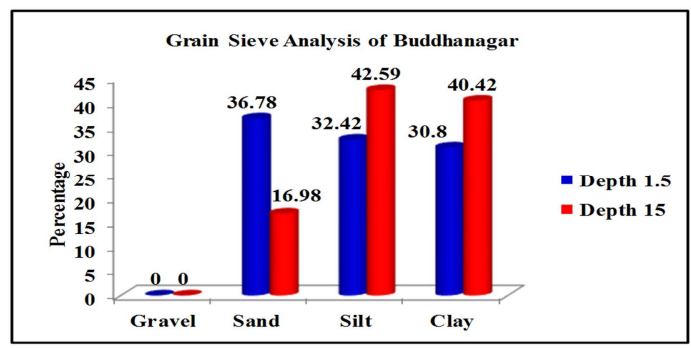

Figure 36. Grain Sieve Analysis of Budhhanagar (Laboratory Test, 2019).

The grain sieve analysis of Mid- Baneshwor is presented in the figure (Figure 37). The blue and red bars represent the percentage of gravel, sand, silt and clay at depth $1.5 \mathrm{~m}$ and $16.5 \mathrm{~m}$ respectively.

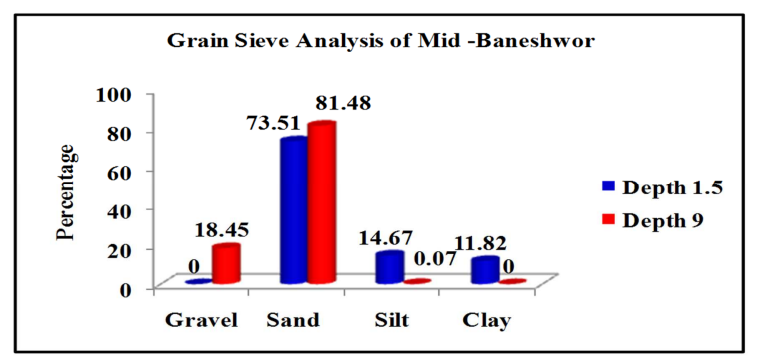

Figure 37. Grain Sieve Analysis of Mid-Baneshwor (Laboratory Test, 2019).

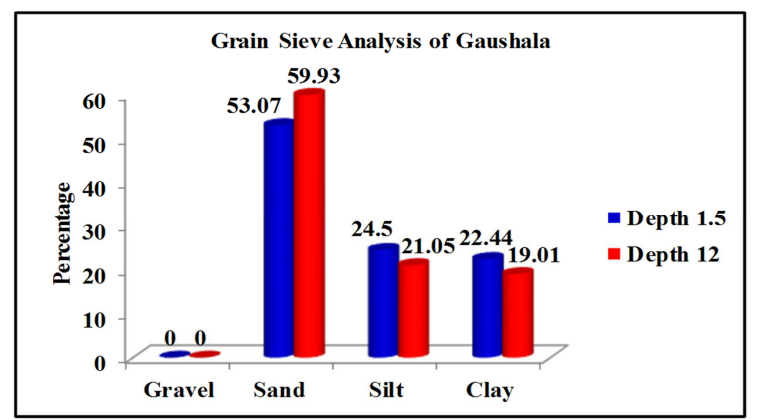

Figure 38. Grain Sieve Analysis of Gaushala (Laboratory Test, 2019).
The grain sieve analysis of Pulchowk is presented in the figure (Figure 38). The blue and red bars represent the percentage of gravel, sand, silt and clay at depth $1.5 \mathrm{~m}$ and $16.5 \mathrm{~m}$ respectively.

\subsection{Bearing Capacity}

The soil type, depth of footing, $\mathrm{N}$ value, bearing capacity at different locations of study area are presented in below table 3 .

Table 3. Bearing Capacity (Laboratory Test, 2019).

\begin{tabular}{|c|c|c|c|c|c|}
\hline S. $\mathbf{N}$. & Location & N Value & Soil Type & $\begin{array}{l}\text { Depth } \\
\text { of } \\
\text { footing }\end{array}$ & $\begin{array}{l}\text { Bearing } \\
\text { Capacity } \\
\left(\mathrm{Kn} / \mathbf{m}^{2}\right)\end{array}$ \\
\hline \multicolumn{6}{|c|}{ a.Lalitpur } \\
\hline 1 & Pulchowk & 5 to 38 & Medium Dense & 4 & 113 \\
\hline 2 & Phulbarichowk & 3 to 39 & Medium Dense & 2.5 & 126 \\
\hline 3 & Bhaisepati & 30 to $50+$ & Very Dense & 2 & 102 \\
\hline 4 & Lagankhel & 6 to $50+$ & Very Dense & 1.5 & 151.2 \\
\hline 5 & Chakupat & 4 to 13 & Loose & 2 & 78.4 \\
\hline 6 & Balkumari & 4 to 16 & Loose & 4 & 80 \\
\hline 7 & Nakhu & 7 to $50+$ & Loose to Dense & 1.5 & 151 \\
\hline 8 & Imadol & 6 to 16 & Loose & 2 & 85.45 \\
\hline 9 & Sanepa & 4 to 9 & Loose & 4.5 & 75 \\
\hline 10 & Bagdole & 5 to 12 & Loose & 2 & 61.66 \\
\hline \multicolumn{6}{|c|}{ b.Bhaktapur } \\
\hline 1 & $\begin{array}{l}\text { Sundarnagar- } \\
\text { 3, Thimi }\end{array}$ & 18 to $50+$ & Dense & 1.5 & 146 \\
\hline 2 & Sirutar & 5 to 30 & Medium Dense & 1.5 & 89 \\
\hline 3 & $\begin{array}{l}\text { Madhyapur, } \\
\text { Thimi }\end{array}$ & 5 to 36 & Loose to med dense & 2 & 101 \\
\hline 4 & Balkot & 7 to 17 & Loose & 1.5 & 93 \\
\hline 5 & Duwakot & 2 to 24 & Loose & 3 & 56.4 \\
\hline 6 & Jagati & 5 to 41 & Medium Dense & 2 & 56.67 \\
\hline 7 & Ram-Mandir-4 & 8 to 15 & Loose & 2 & 88.9 \\
\hline 8 & Balkot & 4 to 39 & Loose to Dense & 1.5 & 67 \\
\hline 9 & Bageshwori & 4 to 22 & Loose to Med Dense & 2 & 76.8 \\
\hline 10 & $\begin{array}{l}\text { Suryabinayak- } \\
\text { 7, Gundu }\end{array}$ & 20 to $50+$ & Med to Very Dense & 1.5 & 142 \\
\hline \multicolumn{6}{|c|}{ c.Kathmandu } \\
\hline 1 & Teku & 4 to 43 & Loose to Dense & 4 & 96 \\
\hline 2 & Maitighar & 2 to 27 & Loose & 5.1 & 68 \\
\hline 3 & $\begin{array}{l}\text { New } \\
\text { Baneshwor }\end{array}$ & 5 to 43 & Loose to Dense & 1.5 & 111.77 \\
\hline 4 & Soaltimode & 2 to 14 & Loose & 3 & 56.6 \\
\hline 5 & Thapagaun & 12 to 37 & Medium Dense & 1.5 & 95.1 \\
\hline 6 & Bafal & 4 to 28 & Loose to Med Dense & 1.5 & 94.81 \\
\hline 7 & $\begin{array}{l}\text { Boudha, } \\
\text { Tinchuli }\end{array}$ & 4 to 41 & Loose to Very Dense & 2.5 & 83.33 \\
\hline 8 & Baluwatar & 5 to 46 & Loose to Very Dense & 4 & 149 \\
\hline 9 & Sinamangal & 11 to 39 & Medium Dense & 3.5 & 120 \\
\hline 10 & Bagbazar & 14 to 37 & Medium Dense & 6 & 71.7 \\
\hline 11 & Kamaladi & 4 to 21 & Loose to Med Dense & 3 & 123 \\
\hline 12 & Panipokhari & $\begin{array}{l}6 \text { to } 50 \\
\text { Above }\end{array}$ & Loose to Very Dense & 3.5 & 158 \\
\hline 13 & Bhatbhateni & 10 to 42 & Loose to Dense & 2 & 115 \\
\hline 14 & Tangal & 5 to $50+$ & Med to Very Dense & 4 & 163 \\
\hline 15 & Budhhanagar & 4 to 10 & Loose & 1.5 & 62.5 \\
\hline 16 & Baneshwor & 4 to 38 & Medium Dense & 3 & 93 \\
\hline 17 & Gaushala & 10 to 38 & Med Dense to Dense & 3 & 156 \\
\hline
\end{tabular}

The bearing capacity of soil is different in different sites. The highest bearing capacity was determined at Lagankhel and lowest at Bagdole in Lalitpur District and the value were $151.2 \mathrm{Kn} / \mathrm{m}^{2} \& 61.66 \mathrm{Kn} / \mathrm{m}^{2}$ respectively. The details of the bearing capacity are presented in figure (Figure 39). 


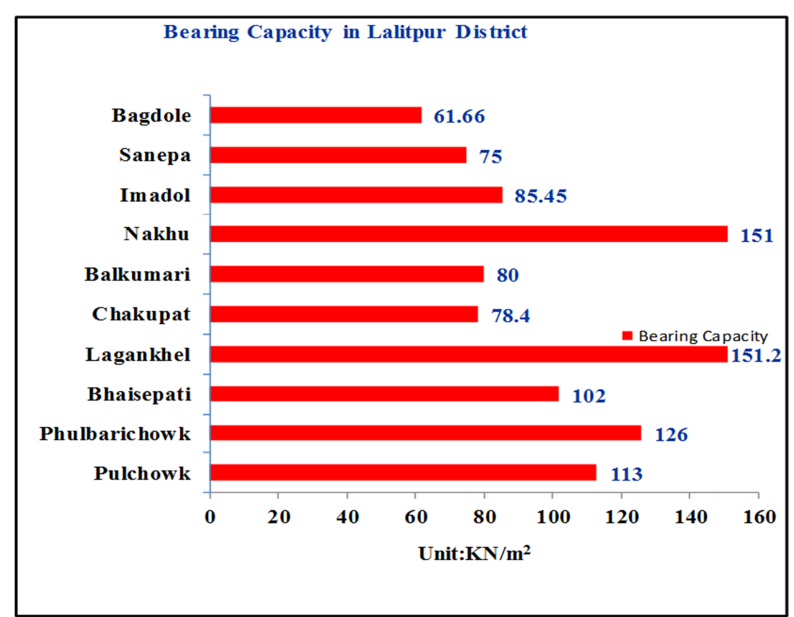

Figure 39. Bearing capacity of Lalitpur District (Laboratory Test, 2019).

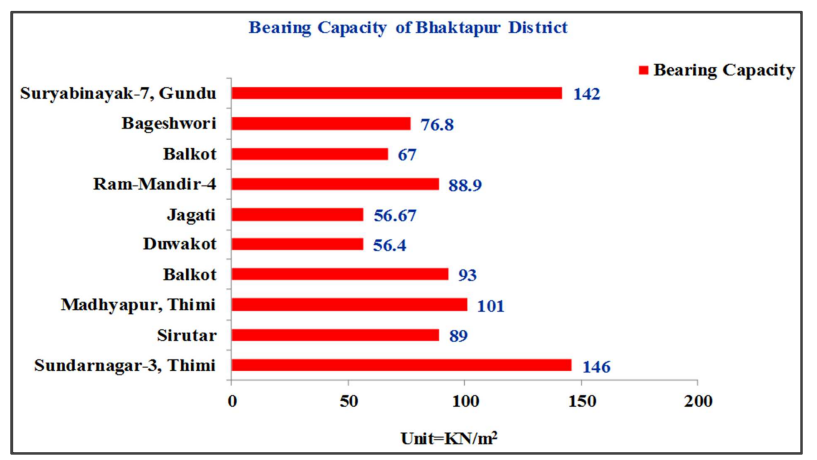

Figure 40. Bearing capacity of Bhaktapur District (Laboratory Test, 2019).

The figure (Figure 40) represents the highest and lowest bearing capacity in Bhaktapur district were determined at Sundarnagar-3 Thimi (146 Kn/m²) and Duwakot (56.4 $\mathrm{Kn} / \mathrm{m}^{2}$ ) respectively.

The figure (Figure 41) represents the highest and lowest bearing capacity in Kathmandu district were determined at Tangal $\left(163 \mathrm{Kn} / \mathrm{m}^{2}\right)$ and Soaltimode $\left(56.6 \mathrm{Kn} / \mathrm{m}^{2}\right)$ respectively.

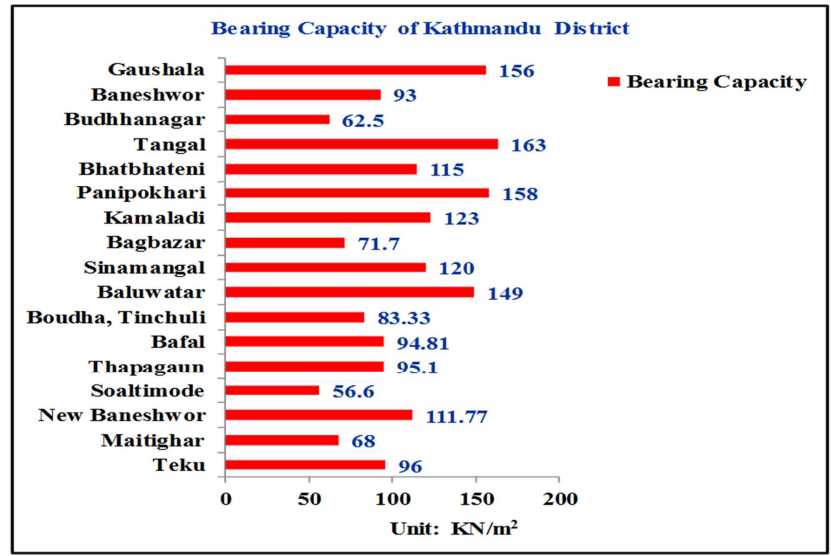

Figure 41. Bearing capacity of Kathmandu District (Laboratory Test, 2019).

\subsection{Bulk density/ NMC/ Specific Gravity}

\subsubsection{Lalitpur District}

The values of Bulk Density at different places of Lalitpur District were found as shown in Table 4. The highest value of bulk density was found to be $2.1 \mathrm{gm} / \mathrm{cm}^{3}$ at Bhaisepati and lowest value was found to be $1.62 \mathrm{gm} / \mathrm{cm}^{3}$ at Phulbarichowk, Bhaisepati.

Table 4. Value of Bulk Density of Lalitpur District (Laboratory Test, 2019).

\begin{tabular}{|c|c|c|c|c|c|c|c|c|c|c|}
\hline \multicolumn{11}{|c|}{ Bulk Density } \\
\hline Site & Pulchowk & Phulbarichowk, Bhaisepati & Bhaisepati & Lagankhel & Chakupat & Balkumari & Nakhu & Imadol & Sanepa & Bagdole \\
\hline \multirow{10}{*}{$\begin{array}{l}\text { Value } \\
\left(\mathrm{gm} / \mathrm{cm}^{3}\right)\end{array}$} & 1.88 & 2.06 & 1.88 & 2.03 & 1.72 & 2.09 & 2.03 & 1.86 & 1.70 & 1.75 \\
\hline & 1.69 & 1.66 & 2.09 & 2.04 & 1.80 & 1.66 & 1.77 & 1.72 & 1.73 & 1.72 \\
\hline & 1.85 & 2.08 & 2.06 & 1.89 & 1.76 & 1.97 & 2.10 & 1.75 & 1.74 & 1.72 \\
\hline & 1.75 & 1.62 & 1.92 & 2.00 & 1.83 & 1.69 & 1.72 & 1.76 & 1.76 & 1.78 \\
\hline & 1.81 & & 1.82 & 1.90 & & & 2.11 & & 1.72 & \\
\hline & 1.84 & & 2.10 & 1.93 & & & 1.75 & & 1.71 & \\
\hline & & & 1.76 & 2.02 & & & 2.05 & & & \\
\hline & & & 1.83 & 1.83 & & & 1.71 & & & \\
\hline & & & 1.78 & 1.91 & & & & & & \\
\hline & & & 2.08 & & & & & & & \\
\hline
\end{tabular}

The values of Natural Moisture Content were found as in Table 5 at different places of Lalitpur District.

Table 5. Value of NMC of Lalitpur District (Laboratory Test, 2019).

\begin{tabular}{|c|c|c|c|c|c|c|c|c|c|c|}
\hline \multicolumn{11}{|c|}{ Natural Moisture Content } \\
\hline Site & Pulchowk & Phulbarichowk, Bhaisepati & Bhaisepati & Lagankhel & Chakupat & Balkumari & Nakhu & Imadol & Sanepa & Bagdole \\
\hline \multirow[t]{10}{*}{ Value (\%) } & 24.79 & 17.21 & 27.94 & 4.40 & 19.99 & 5.00 & 9.25 & 31.73 & 55.51 & 56.94 \\
\hline & 46.02 & 63.75 & 5.66 & 6.13 & 21.40 & 84.06 & 33.30 & 58.32 & 40.21 & 85.78 \\
\hline & 23.05 & 30.81 & 9.91 & 32.66 & 46.53 & 12.49 & 12.61 & 41.31 & 28.98 & 44.68 \\
\hline & 40.30 & 50.19 & 13.24 & 7.78 & 39.94 & 86.95 & 34.34 & 57.14 & 59.66 & 29.24 \\
\hline & 27.91 & & 37.62 & 30.78 & & & 11.74 & & 43.91 & \\
\hline & 32.02 & & 9.27 & 30.50 & & & 36.39 & & 45.55 & \\
\hline & & & 55.54 & 10.58 & & & 14.32 & & & \\
\hline & & & 99.85 & 28.80 & & & 24.93 & & & \\
\hline & & & 27.40 & 32.36 & & & & & & \\
\hline & & & 9.41 & & & & & & & \\
\hline
\end{tabular}


The value of specific gravity at different places of Lalitpur Districts was found in Table 6. The highest and lowest values of specific gravity were found to be 2.72 and 2.55 respectively.

Table 6. Value of Specific Gravity of Lalitpur District (Laboratory Test, 2019).

\begin{tabular}{|c|c|c|c|c|c|c|c|c|c|c|}
\hline \multicolumn{11}{|c|}{ Specific Gravity } \\
\hline Site & Pulchowk & Phulbarichowk, Bhaisepati & Bhaisepati & Lagankhel & Chakupat & Balkumari & Nakhu & Imadol & Sanepa & Bagdole \\
\hline \multirow{10}{*}{ Value } & 2.66 & 2.70 & 2.66 & 2.70 & 2.58 & 2.70 & 2.72 & 2.65 & 2.53 & 2.55 \\
\hline & 2.60 & 2.59 & 2.70 & 2.65 & 2.59 & 2.59 & 2.60 & 2.60 & 2.58 & 2.55 \\
\hline & 2.67 & 2.71 & 2.71 & 2.67 & 2.55 & 2.69 & 2.70 & 2.58 & 2.60 & 2.55 \\
\hline & 2.58 & 2.58 & 2.67 & 2.71 & 2.60 & 2.58 & 2.61 & 2.59 & 2.58 & 2.58 \\
\hline & 2.65 & & 2.63 & 2.67 & & & 2.70 & & 2.58 & \\
\hline & 2.66 & & 2.70 & 2.65 & & & 2.58 & & 2.55 & \\
\hline & & & 2.60 & 2.71 & & & 2.72 & & & \\
\hline & & & 2.63 & 2.68 & & & 2.59 & & & \\
\hline & & & 2.58 & 2.62 & & & & & & \\
\hline & & & 2.69 & & & & & & & \\
\hline
\end{tabular}

\subsubsection{Bhaktapur District}

The values of bulk density at different places of Bhaktapur District were found which is presented in Table7. The highest and lowest value of bulk density was found to be $2.08 \mathrm{gm} / \mathrm{cm}^{3}$ at Sundarnagar, Thimi and $1.67 \mathrm{gm} / \mathrm{cm}^{3}$ at Balkot.

Table 7. Value of Bulk Density of Bhaktapur District (Laboratory Test, 2019).

\begin{tabular}{llllllllll}
\hline Bulk Density & \multicolumn{1}{l}{$\begin{array}{l}\text { Madhyapur, } \\
\begin{array}{l}\text { Sundarnagar } \\
\text { Thimi }\end{array}\end{array}$} & Sirutar & $\begin{array}{l}\text { Bhimi } \\
\text { Thikot }\end{array}$ & Duwakot & Jagati & Ram Mandir-4 & Balkot3 & Bageshwori & Suryabinayak-7, Gundu \\
\hline 2.00 & 1.86 & 1.87 & 1.85 & 1.70 & 1.76 & 1.75 & 1.67 & 1.88 & 1.99 \\
2.08 & 1.75 & 1.80 & 1.69 & 1.70 & 1.79 & 1.71 & 1.87 & 1.65 & 1.98 \\
& 1.90 & 1.63 & 1.82 & 1.89 & 1.73 & & 1.69 & 2.01 & 1.96 \\
& 1.74 & 1.79 & 1.67 & 1.73 & 1.77 & & 1.89 & & 1.96 \\
& & 1.85 & & & 1.72 & & & & 1.92 \\
\hline
\end{tabular}

The values of Natural Moisture Content at different places of Bhaktapur District were found which is presented in Table 8 .

Table 8. Value of Natural Moisture Content of Bhaktapur District (Laboratory Test, 2019).

\begin{tabular}{|c|c|c|c|c|c|c|c|c|c|c|}
\hline \multicolumn{11}{|c|}{ Nature Moisture Content } \\
\hline Site & $\begin{array}{l}\text { Sundarnagar } \\
\text { Thimi }\end{array}$ & Sirutar & $\begin{array}{l}\text { Madhyapur } \\
\text { Thimi }\end{array}$ & Balkot & Duwakot & Jagati & $\begin{array}{l}\text { Ram } \\
\text { Mandir-4 }\end{array}$ & Balkot2 & Bageshwori & $\begin{array}{l}\text { Suryabinayak-7, } \\
\text { Gundu }\end{array}$ \\
\hline \multirow{6}{*}{ Value $(\%)$} & 23.22 & 26.26 & 24.51 & 27.05 & 50.47 & 27.02 & 28.64 & 23.92 & 25.68 & 30.87 \\
\hline & 10.91 & 70.89 & 48.27 & 36.32 & 66.55 & 30.57 & 57.20 & 33.61 & 34.48 & 20.11 \\
\hline & & 21.33 & 69.56 & 36.17 & 33.02 & 31.42 & & 69.52 & & 18.67 \\
\hline & & 75.95 & 33.46 & 84.47 & 69.61 & 29.73 & & 36.76 & & 10.72 \\
\hline & & & 46.12 & & & 33.22 & & & & 16.03 \\
\hline & & & 74.58 & & & 30.82 & & & & 16.83 \\
\hline
\end{tabular}

The value of specific gravity at different sites of Bhaktapur District was found to be as in Table 9

Table 9. Value of specific gravity of Bhaktapur District (Laboratory Test, 2019).

\begin{tabular}{|c|c|c|c|c|c|c|c|c|c|c|}
\hline \multicolumn{11}{|c|}{ Specific Gravity } \\
\hline Site & Sundarnagar Thimi & Sirutar & $\begin{array}{l}\text { Madhyapur, } \\
\text { Thimi }\end{array}$ & Balkot & Duwakot & Jagati & $\begin{array}{l}\text { Ram } \\
\text { Mandir-4 }\end{array}$ & Balkot2 & Bageshwori & $\begin{array}{l}\text { Suryabinayak-7, } \\
\text { Gundu }\end{array}$ \\
\hline \multirow{6}{*}{ Value } & 2.69 & 2.65 & 2.65 & 2.63 & 2.55 & 2.63 & 2.59 & 2.65 & 2.6 & 2.63 \\
\hline & 2.72 & 2.58 & 2.67 & 2.59 & 2.58 & 2.66 & 2.55 & 2.67 & 2.56 & 2.60 \\
\hline & & 2.66 & 2.66 & 2.62 & 2.59 & 2.62 & & 2.63 & & 2.60 \\
\hline & & 2.59 & 2.65 & 2.58 & 2.58 & 2.66 & & 2.68 & & 2.69 \\
\hline & & & 2.65 & & & 2.60 & & & & 2.63 \\
\hline & & & 2.61 & & & 2.67 & & & & 2.60 \\
\hline
\end{tabular}

\subsubsection{Kathmandu District}

The table (Table 10) represents the bulk densities of sites of Kathmandu District were found. 
Table 10. Bulk Density (Laboratory Test, 2019).

\begin{tabular}{|c|c|c|c|c|c|c|c|c|}
\hline \multirow[b]{2}{*}{ Site } & \multicolumn{8}{|c|}{ Bulk Density } \\
\hline & Teku & Maitighar & New Baneshwor & Soaltimode & Thapagaun & Bafal & Boudha, Tinchuli & Baluwatar \\
\hline \multirow{13}{*}{ Value $\mathrm{gm} / \mathrm{cm}^{3}$} & 1.96 & 1.98 & 1.75 & 1.70 & 1.97 & 1.69 & 1.77 & 1.82 \\
\hline & 1.72 & 1.53 & 1.97 & 1.67 & 1.75 & 1.67 & 1.89 & 1.72 \\
\hline & 1.93 & 1.51 & 1.70 & 1.71 & 1.90 & 1.96 & 1.92 & 1.91 \\
\hline & 1.71 & 1.61 & 1.96 & 1.73 & 1.91 & 1.74 & 1.87 & 1.80 \\
\hline & 1.90 & 1.73 & 1.71 & & & & 2.06 & 1.83 \\
\hline & 1.72 & 1.55 & 1.98 & & & & 1.89 & 1.75 \\
\hline & 1.77 & 1.69 & & & & & 1.78 & \\
\hline & 1.95 & 1.71 & & & & & & \\
\hline & 1.76 & 1.72 & & & & & & \\
\hline & & 1.61 & & & & & & \\
\hline & & 1.57 & & & & & & \\
\hline & & 1.59 & & & & & & \\
\hline & & 1.66 & & & & & & \\
\hline
\end{tabular}

Table 10. Continued.

\begin{tabular}{|c|c|c|c|c|c|c|c|c|c|}
\hline \multirow{2}{*}{ Site } & \multicolumn{9}{|l|}{ Bulk Density } \\
\hline & Sinamangal & Bagbazar & Kamaladi & Panipokhari & Bhatbhateni & Tangal & Budhhanagar & Baneshwor & Gaushala \\
\hline \multirow{8}{*}{ Value $\mathrm{gm} / \mathrm{cm}^{3}$} & 1.89 & 1.93 & 1.97 & 1.90 & 1.87 & 1.97 & 1.78 & 1.73 & 1.84 \\
\hline & 1.84 & 1.72 & 1.67 & 1.92 & 1.93 & 1.93 & 1.75 & 1.94 & 1.86 \\
\hline & 1.75 & 2.12 & 1.99 & 1.94 & & 2.09 & 1.72 & 1.84 & 2.08 \\
\hline & 1.86 & & 1.68 & 1.90 & & 1.85 & 1.66 & 1.91 & 1.87 \\
\hline & & & & 1.91 & & & & & 2.07 \\
\hline & & & & & & & & & 1.89 \\
\hline & & & & & & & & & 2.00 \\
\hline & & & & & & & & & 1.78 \\
\hline
\end{tabular}

The table (Table 11) represents the Natural Moisture Content of sites of Kathmandu District were found to be $99.8 \%$ as maximum value at Teku and $4.76 \%$ as minimum value which was also found at Teku.

Table 11. Natural Moisture Content (Laboratory Test, 2019).

\begin{tabular}{|c|c|c|c|c|c|c|c|c|c|}
\hline \multirow{2}{*}{ Site } & \multicolumn{9}{|c|}{ Natural Moisture Content } \\
\hline & Teku & Maitighar & New Baneshwor & Soaltimode & Thapagaun & Bafal & Boudha, Tinchuli & Baluwatar & Sinamangal \\
\hline \multirow{15}{*}{ Value $\%$} & 4.76 & 18.60 & 29.57 & 69.87 & 6.17 & 66.86 & 25.68 & 18.12 & 9.88 \\
\hline & 78.22 & 80.37 & 26.17 & 66.01 & 50.52 & 77.08 & 13.53 & 66.78 & 23.65 \\
\hline & 22.75 & 71.88 & 42.60 & 43.40 & 31.85 & 43.90 & 27.15 & 23.55 & 23.22 \\
\hline & 77.32 & 84.97 & 35.99 & 68.33 & 41.48 & 63.14 & 20.77 & 48.01 & 21.10 \\
\hline & 32.03 & 70.71 & 7.23 & & & & 11.41 & 27.62 & \\
\hline & 99.80 & 66.28 & 9.97 & & & & 22.52 & 48.02 & \\
\hline & 22.27 & 69.85 & & & & & 19.08 & & \\
\hline & 85.06 & 89.13 & & & & & 13.85 & & \\
\hline & 22.63 & 44.71 & & & & & & & \\
\hline & 77.80 & 71.39 & & & & & & & \\
\hline & & 75.86 & & & & & & & \\
\hline & & 80.50 & & & & & & & \\
\hline & & 76.91 & & & & & & & \\
\hline & & 74.18 & & & & & & & \\
\hline & & 66.53 & & & & & & & \\
\hline
\end{tabular}

Table 11. Continued.

\begin{tabular}{|c|c|c|c|c|c|c|c|c|}
\hline \multirow{2}{*}{ Site } & \multicolumn{8}{|c|}{ Natural Moisture Content } \\
\hline & Bagbazar & Kamaladi & Panipokhari & Bhatbhateni & Tangal & Budhhanagar & Baneshwor & Gaushala \\
\hline \multirow{8}{*}{ Value \% } & 16.79 & 7.03 & 15.02 & 12.44 & 10.35 & 21.00 & 38.62 & 31.13 \\
\hline & 32.06 & 67.97 & 15.55 & 20.24 & 26.78 & 52.77 & 22.9 & 43.95 \\
\hline & 7.43 & 17.84 & 30.31 & & 21.64 & 31.88 & 32.75 & 9.76 \\
\hline & & 68.29 & 20.23 & & 21.35 & 47.13 & 31.96 & 43.30 \\
\hline & & & 20.42 & & & & & 22.32 \\
\hline & & & & & & & & 37.89 \\
\hline & & & & & & & & 17.12 \\
\hline & & & & & & & & 19.98 \\
\hline
\end{tabular}


The table (Table 12) represents the Specific Gravity of sites of Kathmandu District was found.

Table 12. Specific Gravity (Laboratory Test, 2019).

\begin{tabular}{|c|c|c|c|c|c|c|c|c|c|}
\hline \multirow{2}{*}{ Site } & \multicolumn{9}{|c|}{ Specific Gravity } \\
\hline & Teku & Maitighar & New Baneshwor & Soaltimode & Thapagaun & Bafal & Boudh Tinchuli & Baluwatar & Sinamangal \\
\hline \multirow{13}{*}{ Value } & 2.63 & 2.70 & 2.55 & 2.63 & 2.69 & 2.59 & 2.60 & 2.66 & 2.69 \\
\hline & 2.55 & 2.61 & 2.68 & 2.60 & 2.60 & 2.58 & 2.66 & 2.58 & 2.66 \\
\hline & 2.60 & - & 2.59 & 2.60 & 2.67 & 2.68 & 2.66 & 2.69 & 2.60 \\
\hline & 2.58 & 2.60 & 2.69 & 2.58 & 2.68 & 2.59 & 2.67 & 2.66 & 2.63 \\
\hline & 2.60 & - & 2.58 & & & & 2.70 & 2.65 & \\
\hline & 2.55 & 2.62 & 2.69 & & & & 2.67 & 2.60 & \\
\hline & 2.63 & & & & & & 2.66 & & \\
\hline & 2.55 & 2.60 & & & & & 2.67 & & \\
\hline & 2.63 & & & & & & & & \\
\hline & 2.58 & 2.59 & & & & & & & \\
\hline & & 2.63 & & & & & & & \\
\hline & & 2.60 & & & & & & & \\
\hline & & 2.59 & & & & & & & \\
\hline
\end{tabular}

Table 12. Continued.

\begin{tabular}{|c|c|c|c|c|c|c|c|c|}
\hline \multirow{2}{*}{ Site } & \multicolumn{8}{|c|}{ Specific Gravity } \\
\hline & Bagbazar & Kamaladi & Panipokhari & Bhatbhateni & Tangal & Budhhanagar & Baneshwor & Gaushala \\
\hline \multirow{8}{*}{ Value } & 2.60 & 2.68 & 2.66 & 2.66 & $2.69^{\circ}$ & 2.64 & 2.6 & 2.67 \\
\hline & 2.55 & 2.59 & 2.67 & 2.69 & 2.60 & 2.66 & 2.69 & 2.66 \\
\hline & 2.72 & 2.69 & 2.68 & & 2.66 & 2.65 & 2.64 & 2.71 \\
\hline & & 2.58 & 2.67 & & 2.60 & 2.58 & 2.68 & 2.67 \\
\hline & & & 2.68 & & & & & 2.70 \\
\hline & & & & & & & & 2.66 \\
\hline & & & & & & & & 2.70 \\
\hline & & & & & & & & 2.63 \\
\hline
\end{tabular}

\subsection{Comparison of Different Parameters at $3 m$ Depth}

The figure (Figure 42) represents the highest bearing capacity among three districts of study area was found to be of Tangal, Kathmandu with a value of $163 \mathrm{Kn} / \mathrm{m}^{2}$. The lowest bearing capacity was found to be of $56.4 \mathrm{Kn} / \mathrm{m}^{2}$ at Duwakot, Bhaktapur.

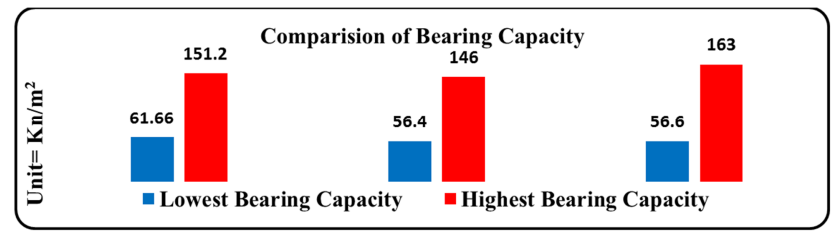

Figure 42. Comparison of bearing capacity (Laboratory Test, 2019).

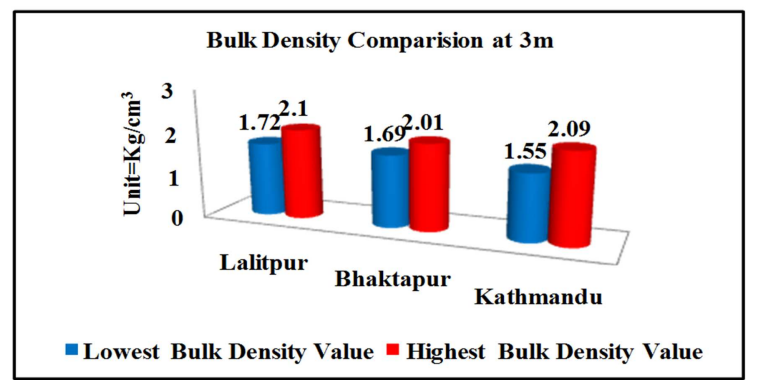

Figure 43. Comparison of bulk density (Laboratory Test, 2019).

The figure (Figure 43) represents the highest and lowest value of bulk density among three districts of study area were found to be $2.1 \mathrm{~kg} / \mathrm{cm}^{3}$ at Lagankhel, Lalitpur and $1.55 \mathrm{~kg} / \mathrm{cm}^{3}$ at Kalimati, Kathmandu respectively.

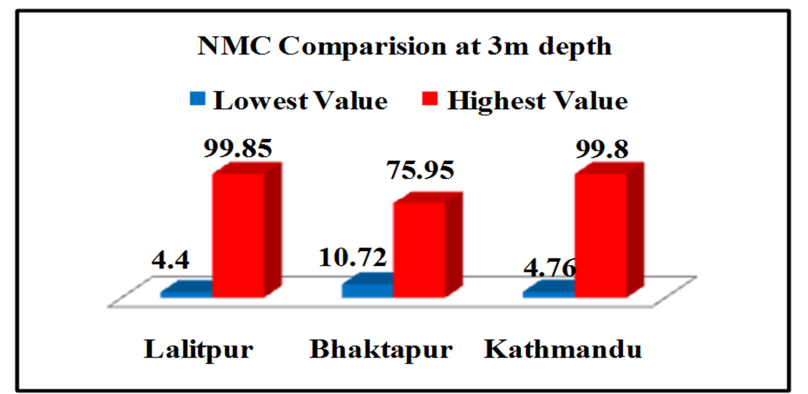

Figure 44. Comparison of natural moisture content (Laboratory Test, 2019).

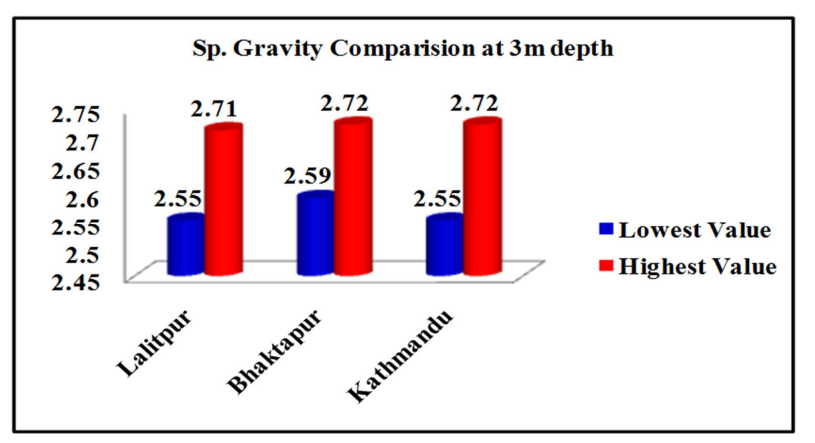

Figure 45. Comparison of specific gravity at $3 \mathrm{~m}$ depth (Laboratory Test, 2019).

The figure (Figure 44) represents the highest and lowest value of natural moisture content at $3 \mathrm{~m}$ depth were found to 
be $99.85 \%$ at Bhaktapur district and $4.4 \%$ at Lalitpur respectively.

The highest and lowest values of specific gravity at $3 \mathrm{~m}$ depth were found to be 2.71 and 2.55 respectively as shown in Figure 45.

\subsection{Ground Water Table Status}

The figure (Figure 46) represents the highest and lowest value of water table is $0.5 \mathrm{~m}$ and $6 \mathrm{~m}$ respectively in Lalitpur District.

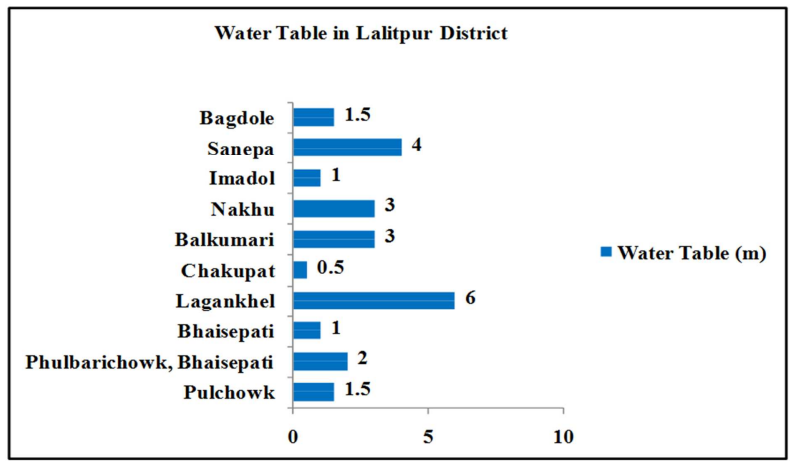

Figure 46. Water table (Field Survey, 2019).

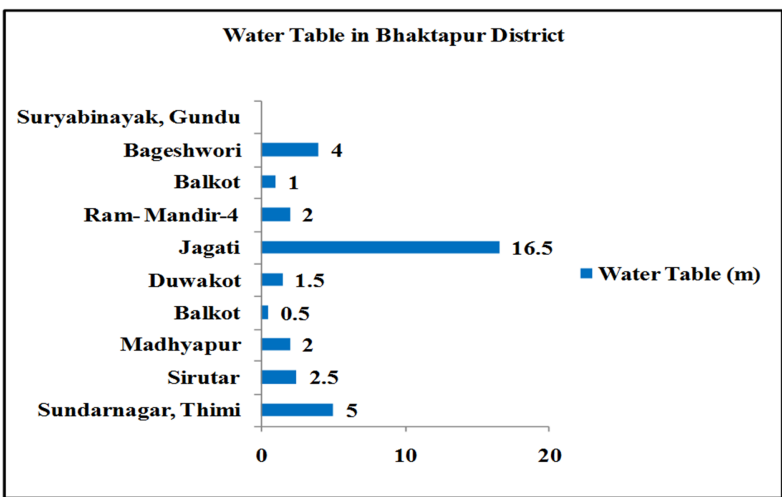

Figure 47. Water Table (Field Survey, 2019).

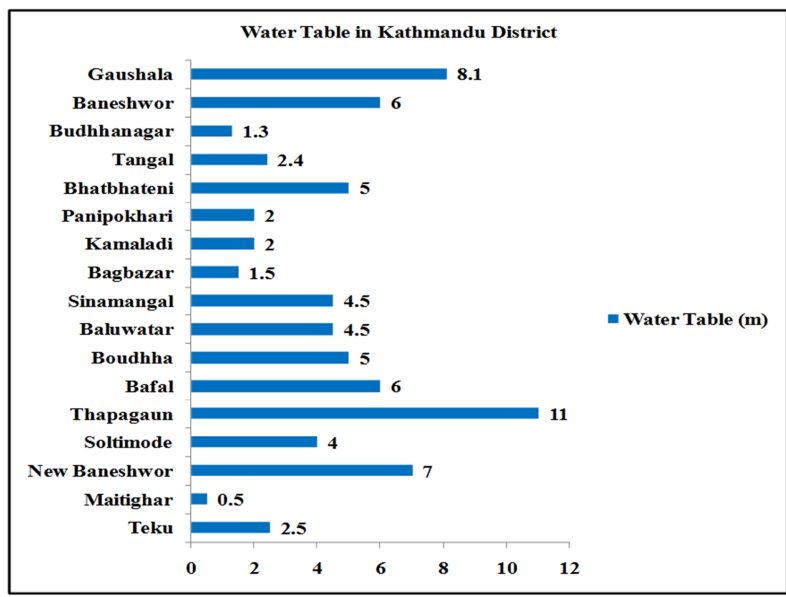

Figure 48. Water Table (Field Survey, 2019).

The figure (Figure 47) represents the highest and lowest values of water table were found to be $16.5 \mathrm{~m}$ and $0.5 \mathrm{~m}$ respectively in Bhaktapur district.

The figure (Figure 48) represents the highest and lowest value of water table was found to be $0.5 \mathrm{~m}$ and $11 \mathrm{~m}$ respectively in Kathmandu district.

\subsection{Comparison of Water Table}

The water table comparison among three districts is presented in Figure 49 (Figure 49).

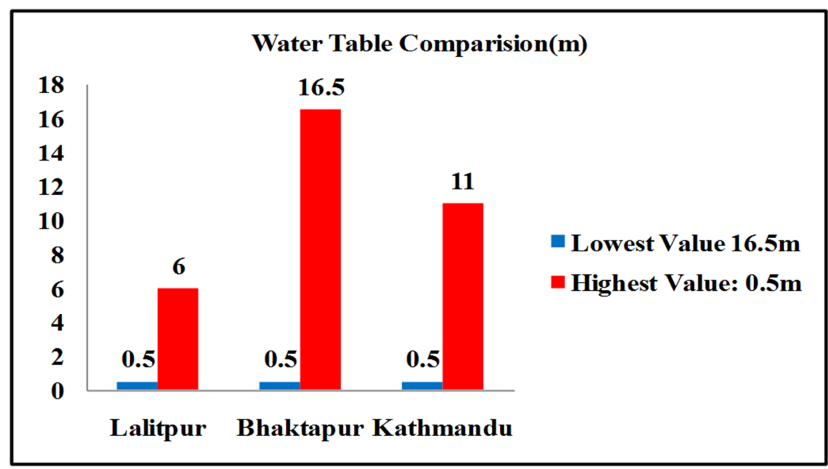

Figure 49. Comparison of water table (Field Survey, 2019).

This research study involves soil investigation for different types of building. The hospital building and religious building were found to be $5 \%$, government building was found to be $11 \%$, residential building was found to be $30 \%$ and commercial building was found to be $49 \%$. Figure 50 shows the types of building involved in this research study.

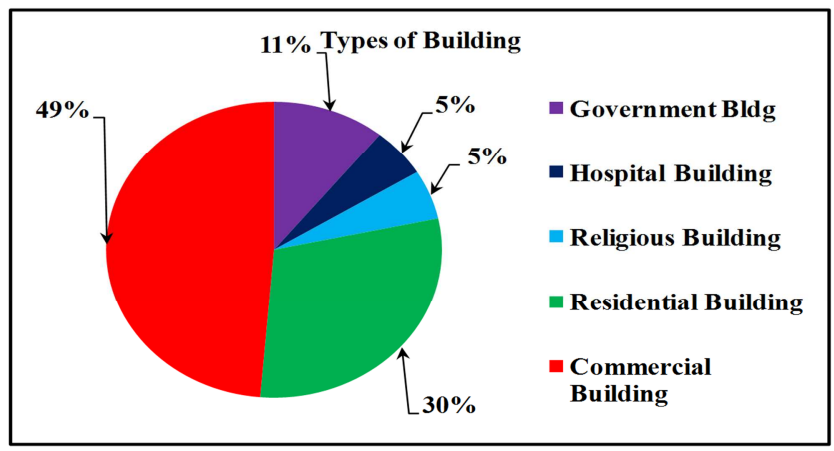

Figure 50. Building Types (Field Survey, 2019).

\section{Discussions}

Nepal's urban area includes one metropolitan town, four sub-metropolitan cities, and fifty three municipalities. KMC, the capital town is the largest urban settlement and holds $22 \%$ of the country's urban population. Speedy urbanization has remodeled the Kathmandu Valley into a metropolitan region: an urban system which is concentrated in the city core enclosed by community areas and satellite cities and towns. It contains twenty one municipalities and eight village development committees. These altogether form a highly integrated economic system [16].

In different period of the history, the three major cities of the valley have served as the capital of Nepal. The inhabitants consists of number of different ethno-linguistic 
communities, out of which mainly Newar communities in the city settlements area unit thought-about answerable for the valley's cultural development since the traditional times and these settlements have common options that distinguish them because of the Newari settlements. The uniqueness of the valley's design and settlement patterns is discovered through the organization of the neighborhood, the formation of individual dwellings, and urban areas similarly because of the community areas and buildings. This pattern is considered distinctive even inside the cultural zones of South Asia. Nepal is characterized by multidimensional topography, geology, and climate with various land uses and livelihood patterns. Mountains and Hilly regions cover $77 \%$ whereas flat land known as Terai covers only $23 \%$ [17].

Kathmandu valley with its ancient culture dates back to over 2000 years to the pre-historic Kirat period as mentioned within the city Profile of Kathmandu [18]. The valley was a lake (which has been confirmed by earth science research) and it had been drained out by a Chinese saint, Manjushree. He gets over the ridge of Chobar that lies on the south of Kathmandu valley and created all the water drain out then created the valley for habitation [19].

The design code for basements and foundations in the Republic of Kazakhstan was reaching to shift into Eurocode "Geotechnics-7". Therein case, associate degree approach of foreign researchers utilized in studies conducted by the authors, analysis of variations between the rules and principles of style to Eurocode [20]. As an industry and a discipline, geotechnical investigation in China differs from that in the USA and European countries in its course of evolution and emergence. For over half a century, Chinese geotechnical investigation professionals witnessed continuous technical advances as they undertook independently almost all of China's large-scale construction projects. Based on projects that won the "National Outstanding Engineering Investigation" Gold Medal Awards since the year 2000, this paper discusses the achievements of geotechnical investigation in the context of comprehensive technical ability, project evaluation and analysis, hi-tech applications and engineering monitoring, and analyzes several factors that have hindered the industry's further development and alignment with international practice. Finally, some suggestions are given for future improvement [21].

\section{Conclusions}

The objective of this research was to investigate soil bearing capacity for building construction of Kathmandu Valley based on laboratory tests. The findings were analyzed based on the five parameters. The study found that the soil bearing capacity of the Kathmandu valley is low. Most of the places consist of Silty Clay the consistency of which is very low. The study found that the soil bearing capacity of the Kathmandu valley is low. Most of the places consist of Silty Clay soil, the consistency of which is very low. The study found that the highest and lowest value of bearing capacity was to be $151.2 \mathrm{Kn} / \mathrm{m}^{2}$ and $61.66 \mathrm{Kn} / \mathrm{m}^{2}$ respectively in Lalitpur District. Similarly, the highest and lowest value of bearing capacity of Kathmandu was found to be $163 \mathrm{Kn} / \mathrm{m}^{2}$ and $58.6 \mathrm{Kn} / \mathrm{m}^{2}$ whereas, the same parameter in Bhaktapur, was found to be $6 \mathrm{Kn} / \mathrm{m}^{2}$ and 56.4 $\mathrm{Kn} / \mathrm{m}^{2}$. Furthermore, the highest and lowest value of bulk density of the Lalitpur district was found to be $1.72 \mathrm{gm} / \mathrm{cm}^{3}$ and $2.1 \mathrm{gm} / \mathrm{cm}^{3}$ respectively, and for Bhaktapur it was declared to be $1.69 \mathrm{gm} / \mathrm{cm}^{3}$ and $2.01 \mathrm{gm} / \mathrm{cm}^{3}$ consecutively. In addition, the highest and lowest value of bulk density was calculated to be $1.55 \mathrm{gm} / \mathrm{cm}^{3}$ and $2.09 \mathrm{gm} / \mathrm{cm}^{3}$ for Kathmandu. Whereas, based on natural moisture content, the findings which were observed are the highest and lowest value of $4.4 \%$ and $99.85 \%$ at Lalitpur; and at Bhaktapur $10.72 \%, 75.95 \%$ respectively. Similarly, the highest and lowest value of Kathmandu district was found to be $4.76 \%$ and $99.8 \%$. Moreover, based on specific gravity the highest and lowest values of Lalitpur District are 2.71 and 2.55, and at Bhaktapur district are 2.72 and 2.55, and at Kathmandu district are 2.72 and 2.55 respectively. Thus, the consistency of the soil at most of the places of the Kathmandu Valley ranges from soft to medium soft depending upon the value of $\mathrm{N}$ (i.e. 4 to 8 ). The study would like to suggest that the geotechnical investigation is necessary before the construction of a building in Kathmandu valley. Furthermore, the depth of the foundation should be increased, raft foundation is recommended to a greater extent. And, pile foundation is recommended, where the soil has very low bearing capacity. The study would like to suggest that Geotechnical investigations are necessary. People's awareness should be emphasized. Massive training regarding the geotechnical investigation should be conducted.

\section{References}

[1] A. Arya and N. K. Ameta, "Bearing Capacity Of FoundationReview Paper," Am. J. Eng. Res., vol. 45, no. 6, pp. 42-45, 2017, [Online]. Available: www.ajer.org.

[2] M. Subedi, I. P. Acharya, K. Sharma, and K. Adhikari, "Liquefaction of Soil in Kathmandu Valley From the 2015 Gorkha, Nepal, Earthquake," Gorkha Earthq. 2015 Spec. Nepal Eng. Assoc., vol. 37, no. December, pp. 264-269, 2016.

[3] G. Chiaro, T. Kiyota, R. M. Pokhrel, K. Goda, T. Katagiri, and K. Sharma, "Reconnaissance report on geotechnical and structural damage caused by the 2015 Gorkha Earthquake, Nepal," Soils Found., vol. 55, no. 5, pp. 1030-1043, 2015, doi: 10.1016/j.sandf.2015.09.006.

[4] A. Albatal, H. H. Mohammad, and M. E. Elrazik, "Effect of inadequate site investigation on the cost and time of a construction project," pp. 331-336, Jan. 2014, doi: 10.1201/b16058-49.

[5] H. B. Motra, H. Stutz, and F. Wuttke, "Quality assessment of soil bearing capacity factor models of shallow foundations," Soils Found., vol. 56, no. 2, pp. 265-276, 2016, doi: 10.1016/j.sandf.2016.02.009. 
[6] M. A. Mahamud, M. Alamgir, M. J. Hossain, and E. Section, "Laboratory Investigation on the Behaviour of Improved Organic Soil of Khulna Region,” no. 1, pp. 1-7, 1938.

[7] V. Subramaniam, "Analysis of vit soil," no. November, 2019.

[8] M. F. Ovi, Deep foundation in Bangladesh. 2015.

[9] M. Dixit and K. Patil, "Study of Effect of Different Parameters on Bearing," no. April, 2016.

[10] H. A. Abdul-husain, "Comparison of Theoretical Ultimate Bearing Capacity of Cohesionless Soils with Experimental And Field Data," no. 3, pp. 596-603, 2016.

[11] R. K. Danai and I. P. Acharya, "Bearing Capacity Analysis and Zoning of Kathmandu for Shallow Foundations," J. Adv. Coll. Eng. Manag., vol. 4, no. December 2018, pp. 111-117, 2018, doi: $10.3126 /$ jacem.v4i0.23200.

[12] Z. Erguler, "A quantitative method of describing grain size distribution of soils and some examples for its applications," Bull. Eng. Geol. Environ., vol. 75, Sep. 2015, doi: 10.1007/s10064-015-0790-1.

[13] D. Cummings and F. J. Kenton, "Eleven Case Studies of Failures in Geotechnical Engineering, Engineering Geology, and Geophysics : How They Could Have Been Avoided," Fifth Int. Conf. Case Hist. Geotech. Eng., pp. 0-12, 2004.

[14] R. Shivashankar, "Scholars ' Mine Role of Case Histories on
Geotechnical Engineering Teaching and Practice ROLE OF CASE HISTORIES IN GEOTECHNICAL," no. May, pp. 010, 2013.

[15] A. A. G. AL-SHAMMARY, A. Z. KOUZANI, A. KAYNAK, S. Y. KHOO, M. NORTON, and W. GATES, "Soil Bulk Density Estimation Methods: A Review," Pedosphere, vol. 28, no. 4, pp. 581-596, 2018, doi: 10.1016/S10020160(18)60034-7.

[16] E. Muzzini and G. Aparicio, Urban Growth and Spatial Transition in Nepal. 2013.

[17] A. Dhungel, "Introduction to Kathmandu Valley," no. December, 2017.

[18] B. K. Shrestha, "Transformation of Machendra Bahal at Bungamati - Conservation and Management Plan -," pp. 1-15, 2001.

[19] R. B. Thapa and Y. Murayama, "City profile: Kathmandu.," no. December 2017, 2008.

[20] Z. Moh, "Site investigation and geotechnical failures," Int. Conf. Struct. Found. Fail., 2004.

[21] Zhang, Z. (2011). Achievements and problems of geotechnical engineering investigation in China. Journal of Zhejiang University - Science A: Applied Physics \& Engineering, 12, 87-102. 